\title{
A FEASIBILITY STUDY FOR THE COMPUTERIZED AUTOMATION OF THE ANNAPOLIS FIELD OFEICE OF EPA REGION III
}

Henry S, Ames

George W. Barton, Ir.

Roman I. Bystroff

Richard W. Crawford

Arthur M. Kray

Michael D. Maples

Alugust 1976

Prepared for U.S. Energy Research \& Development

Administration under contract No. W-7405-Eng.48

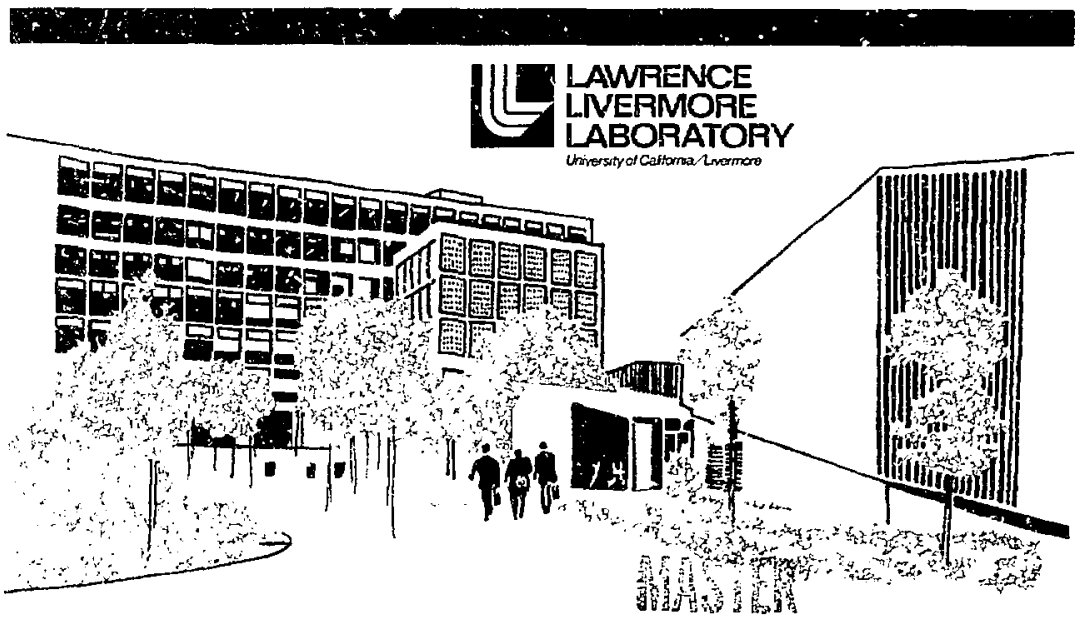

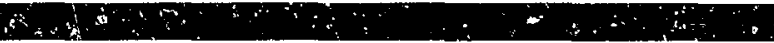

Prepared under Interagency Agreemene EPA-IAG-D6-0321 by the General Chemistry Division of the Chemiatry and Materials Scfence Department of Lawrence Livermore Laboratory. 


\section{NOTICE}

This repon was presurt as as account al wolk spunsored by the United Suates Govemment. Nenthot the United States nor the United States Energy Research \& Development Admentstration, nus any of their eriployees. not any of their conirsictors, substontractors. or theis smployees, ת.ukes any warmants express of umplied, of aseames aly legal liability vi ienponubility for the accuracy. completeness of usefulness of any inforratlon, xpparatur, product or proxess disclused, of tepresents that its ise would not triftires privately woned righis.

\section{NOTICE}

Reference to a company or product neme does tiot imply apsioval or ecommendztion of the, roduce by the Unwersity of Citifornia or the US. Energy Retertht \& Development Admintstrition to the exciuvien of others that may te suitable.

Printed in tlac Utitted Stales of Amertiat Avalabie frons

National Techrical Informatjon Service

U.S. D-parment of Cummerte

5285 Pout Raya! Roud

Spmoplield. VA 22I6I

Price Printed Conys. Murufiche 52.35

\begin{tabular}{|c|c|c|c|}
\hline Pog Rong & $\begin{array}{c}\text { Domestic } \\
\text { Pyes }\end{array}$ & Pags Pange & $\begin{array}{c}\text { Dorreatle } \\
\text { Price }\end{array}$ \\
\hline on!. 025 & 53.50 & 326350 & 10.00 \\
\hline $020-695$ & 4.00 & Iit 175 & ftr. 50 \\
\hline $051-075$ & 4.50 & $376+100$ & 10.75 \\
\hline $076 \quad 100$ & $S . Q$ & $401+1 \leq 5$ & 11.00 \\
\hline $101-125$ & 5.50 & 426450 & $1 i$ is \\
\hline $125-150$ & 6.60 & $451+75$ & $\because \therefore \infty$ \\
\hline $151-175$ & 6.75 & $476 \quad 500$ & 12.50 \\
\hline 176.200 & 7.50 & $50 t-5 \geq 5$ & 12.75 \\
\hline $201-225$ & 75 & $526-550$ & 13.00 \\
\hline $226-250$ & .00 & $551-575$ & 13.50 \\
\hline $251-275$ & .00 & 576600 & 13.75 \\
\hline 276.300 & 9.25 & 601 up & 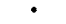 \\
\hline $301-3 \geq 5$ & 9.75 & & \\
\hline
\end{tabular}

- Add 52.5 for caets additíns! 100 page necrement fiom 601 to 1.000 papa

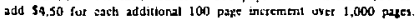




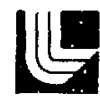

\section{I.AWRENCE IJVERIMORE I.ABORATORY}

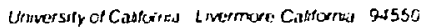

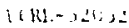

\section{A FEASIBILITY STUDY FOR THE COMPUTERIZED AUTOMATION OF THE ANNAPOLIS FIELD OFFICE OF EPA REGION III}

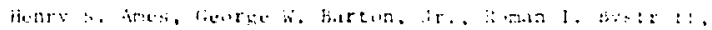

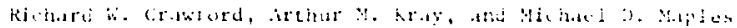

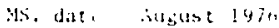

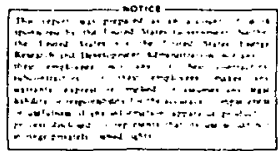




\section{Contents}

Abstract

1. Introduction.

2. Deseription of the Annipolts Field office (AFO) tabotatory . . . . ,

Laboracory Opericlons . . . . . . . . . . . . . . . ,

Analyelcal systeds to be hutumated . . . . . . . . . . . . .

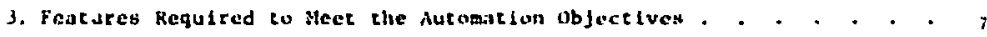

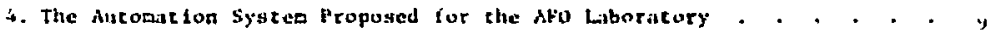

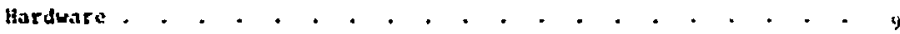

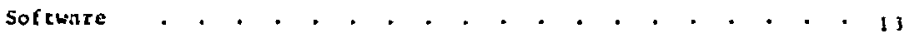

5. Comparison of the froposed system with Mecrnative Approaches . * is

Cose Compirisons. . . . . . . . . . . . . . . . . It

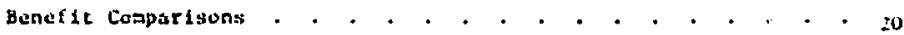

6. Itapace of the Proposed syacem on Afo Liburatory operations * * * 25

Appendix 1. Luidelines followed in traluacins Nuconacion systeas: . . . Lo

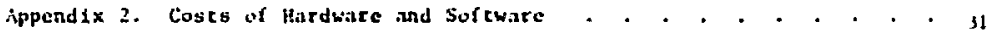

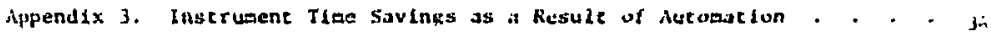

Append1x 4. Nanpawer Savinss do a kegulf of Autopitition . . . . . . 40

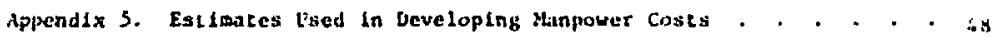

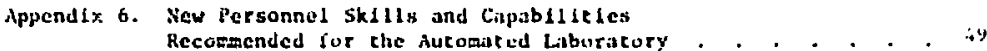




\title{
A FEASIBILITY STUDY FOR THE COMPUTERIZED AUTOMATION OF THE ANNAPOLIS FIELD OFFICE OF EPA REGION III
}

\begin{abstract}
This report describes a feasibility study for computerized automalon of

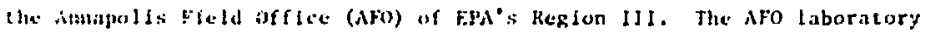
provides analycical suppore for a supber of tPA divisions: Its prtairy func-

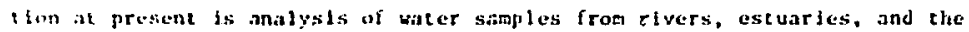

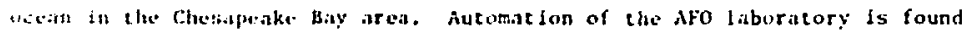
I" he stot anly feitsible but also inikhly desirable. An automiton syster is

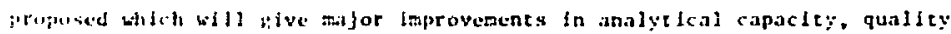

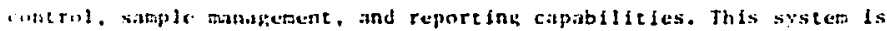
sitilat to the blt-developed autunt ton systems already instalied at other Hid laboralories, with musfications speclfte to the needs of the difo labora-

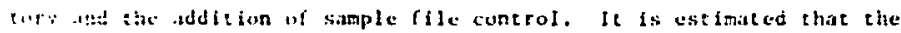
injt..l cast of the sysect. nearly $\$ 300,000$, would be recouped in about thres:

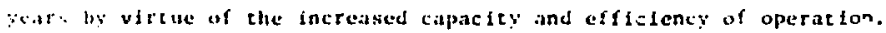

\section{Introduction:}

The Enviromental Protectón Ageracy (EPA) has recognized for some tite that its laboratories would benefie from compulerized autaraton, and since

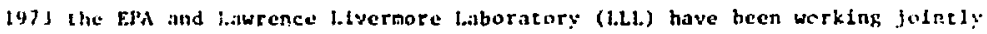
un automicion plans. The approach has been to make individual studies of a fes typical laboribortes and develop automation systems for them that could be reproduced, with mly afnor mediftcations, to serve for ocler similar laboracorfes. Thls effort. conducted under Interagency hgrement No, LPA-LAC-D61321. Has become known as the Pllot Laboratory dutomation firaject. Nembers of che 1.L. Chemistry and Materials Sclence Deparcmene with broad experience in compucer automation of laboratory operations have been assigned to the project. Auz:qut lon systems have already been designed and put into operatlon at three EPA Labcratories: two laboratories of the Envlronmental Research Center at Clncinnatl, and the Ceneral Reglonal Laboratory, Reglon v, at Chlcago. The fourti labcracory studied for autointion is the Region III innapolis Fleld 
Offlce (AFO). ":his :'eport describes the AFO study and the automation system proposed as a result.

There are five major objectives accomnilshed by automating the EPA's sample analysis laboratories:

1. Increased Instrument capacity. The computer helps to maxinize Instrument capacity in several ways. Coucentrations are calculated immediately anci quality control checks are made on stream. On fully autumatic instrumt:nts, the operator is notified imediately if something goes wrong with a run so that it san be corracted. On serimanual operations, the computer saves time between samples by relfeving the operator of the need to read and calcuiate concentrations.

2. Improved accuracy and precision of analytical results. Digital reading of the instruments by a computer is inherently more precise than isual reading and covers a broader dynamic range. In addition, accuracy is improved by using some of the increased sample capacity that the computer provides to run more standards, spikes, and duplicates.

Computer automation provides two Lmportant kinds of quality control (QC). The first kind of $Q C$ is passive; it resulis from the fact that the flow of Information is always under computer superviston, with no hand transcription of data once it is entered into the system. If the system makes a ristake, 1t Is almos: Invariably the k1nd of mistake that humans find preposterous. Sucl, errors are easy to spot.

The second kind of $Q C$ provided by computer autonation is active. The arithinetic power of the computer permits easy implementation of analysis algorithms and statistical tests which are very laborious to do by hand or even with a modern calculator. Additional operator effort is required, but it is minimal. The analyst must pipet duplicate samples and standards, and spike a certain fraction of samples.

Together, these two kinds of QC, passive and active, alert the operator to trends in system behavior and permit him to take corrective action before, or as soon as, false results are produced.

3. Analysts' time saved, tedtum recuced. The computer eastly hardles the tedfous, repetitive work that operators have done in the past and frees them for tasks that better utilize their talents. There are several major ways the computor helps the analyst. It reads all the data and calculates the concentration of samples and the curvec for standards. It keeps track of work 
that needs to be done and wark that has been done and creates tables of outpui data. It retrieves stored data to help with dilutions and provide compliance IImits.

4. Reduced clerical time and errors. The computer saves clerical time and reluces clerical errors bucause 1 elfalnates all hand transcription of information and daca after the initial sample-ldentifying information bas been entered. It will print reports sultable for fi.ling or distribution and will maintijn an inventory logbook.

3. Improved access to the anal;tical data. At least one month's accumulation of analysis data can be stored in computer system files. With the proper software, known here as sample file control, the infortation can be made civailable in a variety of forsats that $c$ n be used in preparing reports. It can also be used for looking at trends of instripental behavier (e.g., calibration drift), checking quality control parameters, and preparing work accountability reports.

In Section 2 of this report we describe the Annapoits Field office and the analytical systems to be automated. Section 3 gives the features we consider important in a laboratory automation system. Section 4 describes the automation system we propose for the AFO laboratory, Section 5 compares the proposed syc m with alternative approaches, and Section 6 discusses the impart of the proposed system on AFO laboratory operations. Details of the analyses used in the evaluations are given in the appendices.

\section{Description of the Annapolis Field Office (AFO) Laboratory}

\section{LABORATORY OPERATIONS}

The Annapolis Field office (AFO) provides analytical support for a number of EPA divisions, Incis: ig Survelllance and Analysis, Enforcoment, and $A 15$ and Water and Hazardous ititrials Concrol. Currently the primary function of Afo Is analysts of water samles from rivers, escuaries, and the ocean in the Chesapeake Bay area. These samples are usually obtained by teams from tne particular office Involved.

Some of the other duties of the AFo laboratory include boctor s:aiment analysis, blological Identification, and analysis of raterial being jumped in the ocean. Laboratory personnel analyze all air bubbler samples taken in Regton III as a part of the Natfonal Air Survellance Network. They monitor 
platt eftiluent to see that standards are being complled with, i task that will becone increasingly important.

Every six months the laboratory and engineering staft plan the rext six month: work load. The engineering staff pichs the surveys. A discriptiun of each task is writen by the engineers and sent to the laboratory. lointly, a weekly schedule is issued showing the expected sampling.

Al1 lquid samples for nutrient analysis arrive at AFo refrlgerated. They are arranged according to parameters request.ad, and un analysis request form is supplied with each sample. The samples are stored In a custory roon. Laboratory personnel then take these samples for Indicated analysts alcording to established priority.

The work required to prepare sample workbooks and wutgisng inalysts reports and correlate sample Identffications with datil I:i a major iler feal burden. Bore important, the analysts spend much of tyefr timi corrilat Iny strip-chart data wth sample identiffcations and maiting quantitatife calculations. Sample identiflcations and data are manualy ranscribed severa! times for each constituent detetmined.

Up to 40 different paranzers may be measured on a sampit. Tlise parameters fnclude about 20 arace metals; several nutrients, such as varfors forms of nitrogen and phosphorus; antons such as chloride, sulfale, cyanide, and iluoride; and tescs for such characteristics as toral olyatic carbon and chemical oxygen demand.

ANALYTICAL SYSTENS TO BE AUTOMATED

\section{Atomic Absorption Spectrumetry}

Trace metals are determined by measting the amount. of light absorbe: by atoms at discrete waveiengths of 1 ight. A hollow-cathode lang ls used to generate a light of discrete wavelength characteristic of th: metal of interest. Part of the sample is cransferred to a flame or furnace in a reproducible manner. The flame converts part of the sample to atoms in the unexcited state, which car absorb the light from the hollow cathode and change the amount of lighi striking a detector. The detector generates an electrical signal which is converted to a voltage proportional to the amount of light absorbed by the metal atoms in the flame. The voltage is recorded and the amount of that particular metal in the test solution is calculated by comparison with a standard solution contatining a known amount of the metal. 
Two atomic absorftion instruments tegecher with one automatic samplar would be atomace. The detector sutput slgnal would be conditioned and interfaced for compucer raiding. The sampler wouls be incerfaced so that the - onputar would control the rotation of the turntable and the raisfab anj lowering, of the aspirator used in flame analysis. A computri analysis algoritlm wold automiticaily tine the positioning of the sampler, tading of the sixinal, ind correlation of the signal with the sample identification number.

Tetonicon dueninal jears*

Tha spectes of incercist is converted to a colored solution by a series (s) precisely controlled chenical reactions that take place in a wntinuously flowint stream in which a known proportion of sample and reagant solucic ns .4T* drawn int, the system and moved through ft by a peristaltic pump. frim isces fur lifferent constituenta zequire difierent steps in the chemical provedure, such as filtration, difestion in hot concentrated acids, reduction, and tine delays to allow each step to reach equilibrlut. Finally, ihe culurcu solution flows througis a colorimeter cell and absorbs jight in the wavelcapth band of tik: colorimeter. The amcunt of light ab;orbed is detected by a plotodetector and recoried as an output voltage on a strip-charc recurder, and the amount of the chemical species of incerest is calculated by comparfirg the recorded voltase with that for a standard solution containing a known amount of tir. decermined specles.

$A$ maximum of 15 channels of Technicon AutoAnalyzers togetber witi their automiatic simplers would be automated. This would consist of six charmels of the Technicon C:SN-6, five channels of Technicon AutoAnal;rar $I$, and four channels of Autohnalyzer II. The detector output signal of each colorimeter would be conditioned and incerfaced for conputer reading. Separate computeranilysis algorithms would be provided for each solorimeter, and they irould autumatically time tie signal reading and corielate signals with sample identification numbers.

\section{Total Organic Carbon Analyzers}

Total organic carbon is determined by combustion of organic matcer to convert the carbon to carbon dfoxide, which is detected as it passes through

\footnotetext{
Reference to a company ot product name does not imply approval or recomer lation of the product by the University of California or the U.S. Energy Research \& Development Administration to the exclusion of others that may be suitablc.
} 
an infrared analyzer. A measured volune of the test solution is injected into a combustion furnace and swept through by a continuously flowing stream of oxygen, converting the jample liquid to water vapor and carbon dioxide. The water vapor is condensed and trapped out as the gases are carried out of the furnace, and the casbon dioxide is carried through the infrared detector and released to the exhaust. The infrared Jetector generates an electrical signal which is converted to a voltage proportional to the amount of carbon dioxide passing through the detector. The voltage is recorded on a stripchart recorder, and the amount of organic carhon present in the injected solution Is calculated by comparing the recorde voltage with that for a standard solution containing a known amount of organic carbon.

The Beckman 915 Total Organfe Carbon Analyzer would be astomated. The detector output signal would be conditioned and interfaced for computer reading. A computer analysis algorithm would automarically time the slgnal reading and correlate the signal with the sample identification numbers.

\section{Exiscing Data-Processing Procedures}

Most of the samples are water samples. When these samples are taken in the fiteld the salinity, temperature, and other parameters are measured and recorded un a fleld card, which accompanies the samples back to the laburatory. Samples for dissolved oxygen are delivered in a speclal bectle with the bottle number already attached to 1t. With each sample is a sample station number and a paramecer code that the field engineer encers on the card describing the sample. There are several types of fleld cards befng ::sed; the most cnmmon are a white and a yellow card. The whice card is used for entering fleld daca for survey-type analyses. The yellow card is used for compliance monttoring: in other words, checking to see if an industry ur a tunicipality is exceeding its licensed amount of discharge. This card has the usual field data entered by engineers, and in addition if has a witnessed chain of custody with dates and times. On the reverse side is space for entering the results of all the desired analyses.

When the sample arrives at the lahoratory an eight-digic sample number is assigned to 1t. The first six digits of this number are the year, conth, and day the sample was taken. The last two digits are the sample number, 1 through 99. If more chan 99 samples come in on any one day, the excess samples are handled by incrementing the date and starting over again with the .umber sequence 1-99, since normally bacches of samples do not arrive daily. 
The cight-digit sample number is then whten cn the slife of the sample container. which is a cublcul polyethylene bottle calied a Clbitalner. These

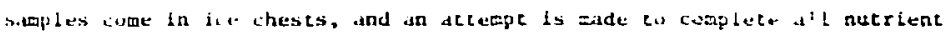

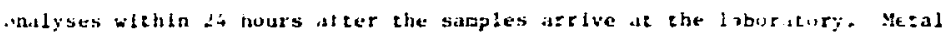
andlyses arte cupluted without chls cunilraint.

The sectetary kecps a series of lab books, one lab be in :ir elach

ditterent type of determination thwi fis done, such as organic iarton, silicon, Latal phosphate. nitrite, nitrate, tec. The analyst pleks up the lab book trial the secretary and enters the results of the deterninations for chat day.

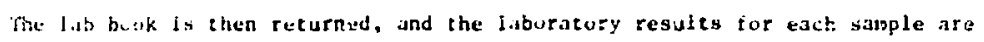
compiled by the seretetary.

i considerable arount of bozh clerical and analytical tife is spent weiting up sitppic wor': sheets and reports, and a majur porcton of thiq analyst's litis is required to correlate stip-chate recordings with susple tdentification rumbers and to calculate values for eisch constituent determbned.

A sample flle control for sample logging and report itriting should be part of the iuccmation system. This system would control aud document each sample's progress from the tme it reaches the sample acceptance station untif the data derived frua it is printed in a final report to the requester.

\section{Features Required to Meet the Automation Objectives}

in this section we ftemize the features requited in a labor.ytory automation system to achieve the automation objectives lisced in fiction 1 . Folated material is given ir appendix $l$, in the form of giuidelines followed in evaiuating various $p$ zopused aucomat fon syszems for tie nFU laboratory. Some of these featuxes tequire ot are enhanced by sacple file control (SFC).

- Operating of the Instruments. The syozem must be abie to taide readings from the vutput of the instrument at the tide a sumpla signal is present, and to sense and control the Insertiun of new sasples.

- Quality control for each parameter. A set of standards, replicaics, and spfkes must be used to assure the correct result for a parameter.

- Analyst's woric-session plan. Given the samples before him, the anelyst should be able to arrange the running sequence $1 n_{\text {i }}$ a pactern with check standards or rerun samples in an order that minimizes interference between samples. (Enhanced by SFC.) 
- Local record of sample activity. The summary of samples completed, partly done, or still to be done should be avallable at every work station. (SFC requlred.)

- Calculation of results. Arithmetic algortthms to calculate resules from standard values, the volume taken, etc., and standard deviations should be included.

- Ease of instrument add-ons. The computer system should be able to accommodate additjonal instruments and perform additional automatic functions. The need for outside help should be minimized.

- off-1ire data manipulation. This important feature, which allows an operacor to use the cowputer as an extremely powerful calculitor, should be built Into the system.

- Ease of reprograming. The user himself mist be able to make necessary changes when new Information, procedures, and operations are instituted.

- Logbook entries. Logbook sntries must Identify the samples, date them for entry, and specify the requested work.

- Analyst's workload selection. The computer must be able to select a batch of samples for a particulirr test from the many in storage. (SFC required.)

- Storage of results. The analytical results must be associated with all else that is known about the sample. (SFC required.)

- Storage of legal/AQC data. The record of custody and records of assurance that the proper procedures were followed are of use in quality control. The attorneys need evidence that acceptable procedures were followed and that the results are valid. (SFC required.)

- Backlog requests. The supervisor must be able to trace work in progress and plan laboratory efforts. (SFC required.)

- Standard and interim reports. A final bard-copy report of :=sults shuuld be readily avallable, as well as interim reports such as the supervisor may need to determine the progress before all work on requested parameters is complete. (Enhanced by SFC.)

- Interparameter quality control. Related parameter results should be self-consistent. An example is the sum of inorganic and organic nitrogen, which must equal total nitrogen. (Simplified by SFC.) 
- Analysts' needs for at least one month's worth of data. The system should bc able to store at least one nonth's back data for effective opera$t$ ion. For example, results of previous work on similar samples ate needed for estimation of dilution factors, and trends in the calibration curves give warning of maintenance that needs to be done. (SFC required.)

\section{The Automation System Proposed for the AFO Laboratory}

The hardware and software proposed for the Annapolis Field office are very similar to those already installed in three other EPA facilities (two at Cincinnati and one at Chicago). The differences are due mainly to improvenents by the supplier, Datil General Corporation, and the need for increased capabilities to improve upon the present systems. The changes do not affect transportability of softriare between facilities.

This description is broken into two tmajor se.tions, hardware and software. The software is hroken into two options: the present programs without chinge, and the present programs with modifications specific to the needs of the Annapolis Field of fice.

HARTWARE

The proposed computer system is designed around a Data General Eclipse $\mathrm{C} / 300$ computer as shown in Fig. 1. A list of the major components and their cost is given in Appendiz 2 (Table 2-1).

This is a maximum configuration which allows the maximum reasonable capability of the system when the ultimate number of instruments are interfaced. Some of these items do not have to -a procured at first, but can be retroficted to the system in the future if expansion is warrante.l. Such items are indicated in the following description of the individual components.

1. Main frame (computer). The computer main frame is the latest generation produced by Data General Corporation, the Eclipse C/300. It is silailar to the Nova 840 computers, which are used in the other EPA facilities. The Eclipse computer is almost twice as fast as the Nova. It uses the same operating system as the Nova, MRDOS, so that most software is transportable.

Twice as much core memory is proposed for the maximum AFO system as in the existing systems. This additional core may be used as a swapping aren 


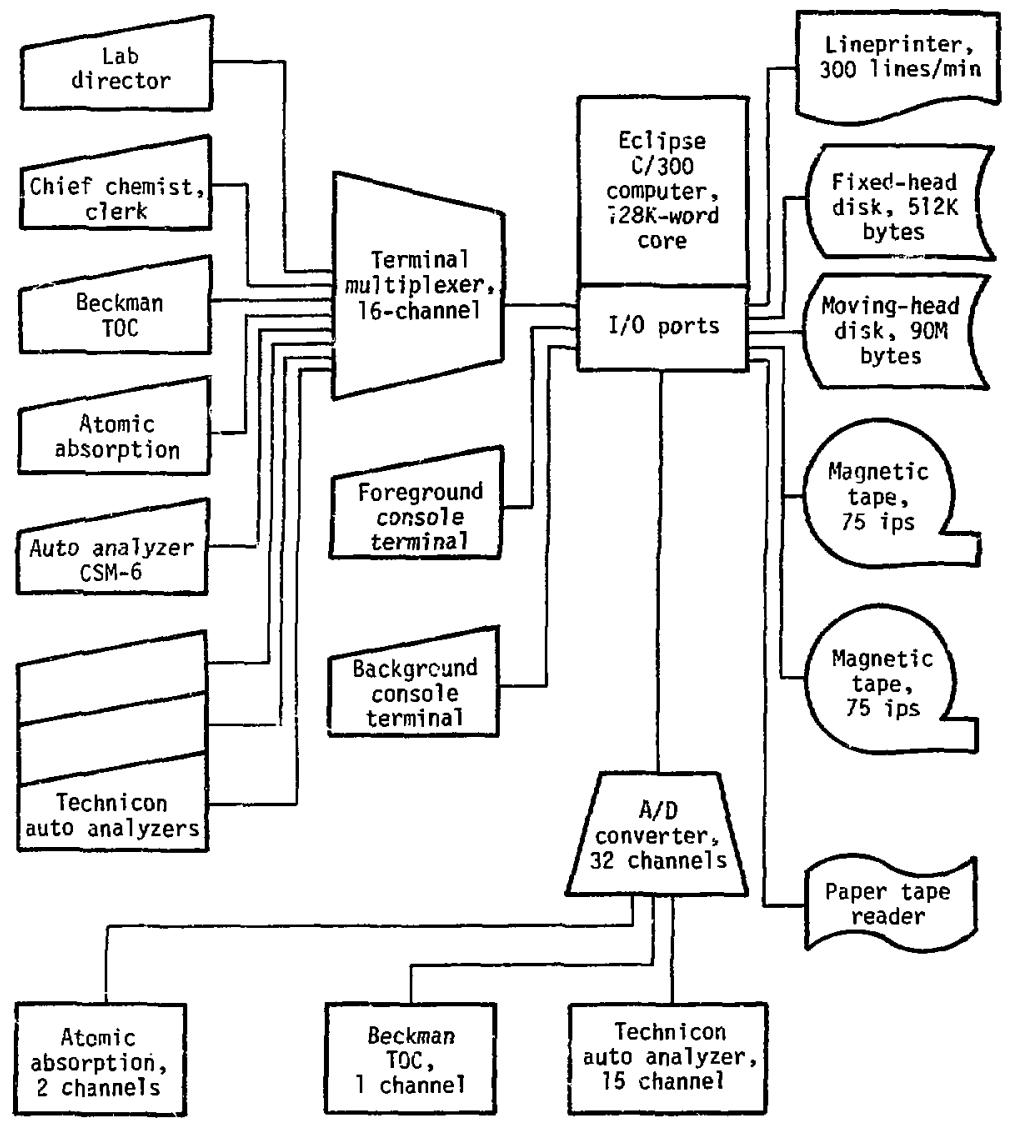

Fig. 1. Schematic of proposed hardware system for the Annapolis Field office. 
for aASL users in potential future revisions. For tine system to be timeshared, various users' programs must be brought into active core and executed, each user getcing a certain amount of time before another user takes over. Most of the BASIC user programs are so large that only one user can it in active core at one time. Therefore, users are presently swapped in and out of core frum a fixed-head disk. It takes approximately 0.2 sec tr transfer from disk $f$ inemory and vice versa. A transfer to and from the extra core could be done in abuut $100 \mu \mathrm{sec}-$ a considerable and worthwhile time saving.

For the present, this additional memory is not included. When all the initial instruments are running simultaneously a mild degradation of response is rotıced by the operators of the existing systems. As additional instruments are interfaced this degradacion may become unacceptable. If so, additional core can be added then.

The E:Lipse $\mathrm{C} / 300$ computer is iecommended because it provides improved File inanagement capabilities through Data General's INFos system. Sample management programs can make use of INFOS to speed the operations log-in, workluad listings, and report generation. A less expensive alternative to the C/300 ( $\$ 32,700)$ might be Data General's S-200 $(\$ 25,700)$. Alchough the $\$-200$ has the same operating system (MRDOS) as the $C / 300$, it is not provided with INFOS. If the $\mathrm{S}-200$ were chosen and at some fucure time INFOS were desired, the S-200 would have to be replaced with a $\mathrm{C} / 300$.

2. Disk storage. A rapid-access storage of programs and data is provided by disk systems. A fixed-head and a moving-head disk are proposed.

The fixed-head disk is used primariiy for overlays and swapping. Its specialty is the ability to find data rasidly, but it is not particularly fast at transferting data, so it is used prinarily with smail files. The proposed fixed-head disk is identical with those in the present systems and has not been very reliable.

The proposed moving-head disk is a considerably faster unit than the one used in the present systems. Although it takes a little longer to find data than the fixed-head disk, it transfers data much faster. As an example, it can transier an average BASIC progran almos: three times as $f_{i t} t$ as the $f_{i}$ "et head and twice as fast as the present moving head. In additior, it provides more storage than the present disk. While this additinnal storage is not neaded to implement the present functional description, no smaller disk drive is available with the desired speed. Its reliability is expected to be 
excellent, since it is built by Control Data Corporation and marketed by them as the CDC 644 and by IBM as the 3330 .

Several open-ended options are possible. We recomend purchasing the fast moving-head disk $(\$ 31,760)$ inftially. The fixed-head swapping disk $(\$ 10,045)$ can be deferred. Response time w1ll be acceptable with the initial instruments installed. When additional instruments are added to the system, the fixed-head swapping disk may be required. As an alternative to the above for the Intial Installation, a slower moving-head disk can be procured $(\$ 10,250)$, but the swapping disk will also be required. This latter alternative gives the minimum cost for acceptable performance.

3. Magnetic tape. Magnetic tape is used as the primary backup medium for the system. It is also important for long-tern bulk strirage and for the transfer of data from one physical losation to another.

The proposed system includes a magnetic tape drive running at 75 inches per second (ips). The present syslems have a variety of tape drives: MERL has 12.5 ips, which is painfully slow; CRL $V$ has 45 Ips; and EMSL has twon, 12.5 ips and 75 ips.

If, in the future, legal requirements make a continuous log of a:l system transactions necessary, additional drives, up to a total of eight, can easily be added.

4. Line printer. One of the major ways in which the computer communicates with the user is through the line printer. It will be used to produce workload listings, sample wheel patterns, notebook tesults, and final results and progress reports, as well as listings of programs.

The proposed line printer is twlce as fast as the present one, printing 300 lines per minute versus 150. It is alsiu considerably quieter.

5. Paper tape reader. The paper tipe reader is used almost entirely for start-up of the system and for diagnosis of hardware problems. As an interim weasure, it has been used to transfer data from instruments with their own computer Into the Data General system. The proposed reader is identical with those in the present systems.

6. Analog-to-digital converter system. The analog-ro-digital converter i. used to read the signals coming from all the different automated instruments. The proposed converter is the same as that found in the present systems.

the proposed converter can measure 32 different signals. It has a resolution of one part in $16,384\left(2^{14}\right)$ of a full-scale signal. 
7. Terminals. The terminals ar the major means of entering information int, the computer system other than the analog-to-digital converter. They are also used to report interim data and warnings during automated runs.

lwo different terminal types are proposed. One is a silent, hard-copy device. Two of these are used with the computer console to control systems operation. At least one other would be available for use wherever hard copy is needed.

The terminal used with all instruments and management is a sathode ray tube (CKI) type. These have the advantage of more rapid display and of not creating large amounts of unnecded paper. Some have the ability to roll back, that is, redisplay information that has already scrolled oif the screen. 1t is proposed that ten terminals be included in the fnitial systen. Additional terninals can be added as needed with future instruments.

8. Instrument incerlaces. These are the unics that convert the output of each instrument co a signal that is usable by the computer. Mso, a digital interface is used to drive the computer-controlled sample wheel. Where possible, untts designed for previous systems will be used. The interfaces for the Technicon CSH-6 AutoAnalyzer, the Perkin-Fimer 305B atomic absorption instrunent, and the Varian Techtron Ai6 atonic absorption spectroptotumeter whll have to be designed, since chese instruments have not been interíaced previously.

9. Sample wheel. A sample wheel that is tully controlled by the conputer is proposed for use with an atomic absorption instrument. Similar wheels have been delivered to other instillations. The whel can hold up to 40 simples and has a sojenuid valve for autumat lo blank injection.

\section{SOFTWAKE}

1. Existing suftware. The following programs are preseaily avallable:

i. Single channel Technicon 11 ducodnalyzer.

b. Up to three channels Technicon II dutodnalyzer.

c. Up to threc channels Technicon I Nutudnalyzer.

d. Beckman total orginic carbon anilyzer finorganic carbon removed with acid).

c. Flame mode, manual arom:c absorption.

f. Flatre mode, autumats (samplo whea!) atualc absorption.

b. Craphice furnace mode, Eanual atodic absorpelon. 
h. Multi-element emisston spectrometer.

1. Mettler electronic balance.

Describing each of these prograns in any detail is beyond the scope of this study. Detailed specifications are available for each as separate documents. There are certain general and simflar functions that most of these programs include:

- A method of creating standard curves using first-, second-, or third-degree polynomials.

- Calculating unknowns by interpoiating between the two nearest standards.

- Immediate display of concentration as soon as unknowns are rur.

- Correction for instrument and reagent blank.

- Calculation of spike recovery.

- Calculation of error in check standards.

- Calculation of difference between duplicates.

- Calculation of statistical error lands, using the Shewhart or Cusum method.

- An operator's notebook report, including all raw and final data.

- A final report for distribution.

2. Modifled software. Since no two laboratories function exactly alike, there are bound to be differences in software needs. Unfortunately, software is the largest part of the cost of any system, and the fewer changes made in it, the less costly the system. Also, it becomes impossible for a sentral facllity such as ERC Cincinnati to maintain the prograns as the different versions proliferate. Modifications should be limited to features that have a wide demand.

It is beyond the scope of this report to spell out all modifications that the Annapolis Field office would like to see. These differences are spelled out in the functional descriptions, Some examples of desired modifications follow:

a. The inclusion of sample file contro., to reduce the analyst's burden and the number of transcription errors between sample log-in and final consolidated reports.

b. The program for the Beckman total organic carbon analyzer modified to look at total carbon and inorganic carbon, and calculate organic carbon by difference. 
c. The Technicon AutoAnalyzer program modified so that inorganic phospho:us and total phosphorus are compared and total K.jeldahl nitrigen and ammonia are compared to catch impossible numbers.

d. The multichannel Technicon AutoAnalyzer programs modified to handie lour to six thannels from the CSM-6.

e. Al] programs modified to include the industrial statistical error band method for stantards.

f. $\Lambda \perp$ programs modifled to store statistical parameters about standards from run to run, so as to allow automatic updating of control limits after about 25 runs of a particular standard type.

g. The atumic absorption programs modified to accept compliance monitoring license limits and to assure immediate rechecks for inarginal or high concentrations of pollutants.

\section{Comparison of the Proposed System with}

\section{Alternative Approaches}

The intention of the Pilot Laboratoly Automation Project is that software and hardware development for any particular EPA laboratory will be transferable to other EPA laboratories. Many operations are similar from one laboratory to another, and thus automated procedures developed for one laboratory can of ten be used in another laboratory with little or no change. The benefits of automation for a given operation may differ from one laboratury to another because of differences in the emphasis given the operation. In this section we compare the costs and benefits of two different approaches to automating the $\Lambda F O$ laboratory versus the alternative of leaving the laboratory as it is. The two automation approaches are: (1) install an automation system with both hardware and software selected from the system developed for the EPA laboratories in Cincinnati and Chicago, and (2) install the existing and tested system with modified software to better sult the $\Lambda F O$ operations (i.e., the system proposed in Section 4 of this report).

We have ruled out consideration of systems from other suppliers because of the existing investment in engineering and software destgn applicable to Data General systems. Over $\$ 400,000$ has been invested in coding and debugging the present programs. More than $40 \%$ of this would have to be repeated for a 
new system; and further, the programs would not be exchangeable with present installations and would have to be maintained by local staff.

\section{COST CONPARISONS}

Table 1 compares the costs of two alternative systems for the AFO laboratory. The alternative of leaving the AFO laboratory as it is, with no further automation, is not shown in Table 1; If it were, all its costs would be zero since it represents ne change in the existlng situation. Explanaclons of the various cost categorles follow.

\section{One-Time Costs}

These are costs tha: are incurred only once in the automation of a given laboratory.

- Computer and peripherals. This is the estimated price, with discounts, of the computer system as of January 1976. A cost comparison of three alternative systems for the AFO laboratory is given in Appendix 2 (Table 2-1). As can be seen, the costs of disk and magnetic-tape storage untts and printers are a majc: fraction of the total cost. Estiuates of software size and storage requirements are also shown in Appendix 2 (Table 2-2).

- Terminals. To be useful to and accepted by the operator, the computer system must be designed so that the operator can interact with it easjly. We recommend placing a terminal at each instrument or logical group of instruments. We estimate a need for ten terminals: one as master console, one for sample flle control, one as a utllity terminal, and seven at instruments. Hard copy terminals and some CRT terminals cost abuar $\$ 1500$ each.

- Site preparation. This is the cost of preparing a roum ro house the computer, a room having adequate electrical service and air conditioning. 1t also includes pulling cables from fnstrument sites to the computer room. A noulnal figure of $\$ 20,000$ is used.

- Installation. This is the cost for LLL to ship, Install, debug, and test the complete system in Annapolis, and to train the users. Interfaces. These costs are estimated from previous installations. In the case of already-destgned modules, only labrication costs are Included, no design costs. Where a new instrument is specified (l.e., one for which an incerface design is not already available), an estimate of the interface design costs is included. Sometimes a model change in an instrument 
Table 1. Comparative costs and benefits of two systems proposed for the AFO laboratory.

\begin{tabular}{|c|c|c|}
\hline & $\begin{array}{l}\text { Existing } \\
\text { EPA } \\
\text { software }\end{array}$ & $\begin{array}{l}\text { Modified } \\
\text { EPA } \\
\text { software }\end{array}$ \\
\hline \multicolumn{3}{|l|}{ One-time costs: } \\
\hline Computer and peripherals & $\$ 98,000$ & $\$ 98,000$ \\
\hline Terminals & 15,000 & 15,000 \\
\hline Site preparation & 20,000 & 20,000 \\
\hline Installation & 33,500 & 33,500 \\
\hline Interfaces & 45,000 & 59,200 \\
\hline Sof tware & 0 & 84,000 \\
\hline Total & $\$ 21.1,500$ & $\$ 309,700$ \\
\hline \multicolumn{3}{|l|}{ Operating expense (annual): } \\
\hline Vendor's hardware maintenance & $\$ 11,760$ & $\$ 11,760$ \\
\hline in-house hardware maintenance & 7,200 & 8,900 \\
\hline In-house software maintenance & - & 34,900 \\
\hline Total & $\$ 18,960$ & $\$ 55,560$ \\
\hline \multicolumn{3}{|l|}{ Operating benefit (annual): } \\
\hline Saving in personnel (FTE) ${ }^{c}$ & 1.55 & 4.97 \\
\hline Equivalent cost saving & $\$ 68,055$ & $\$ 173,450$ \\
\hline $\begin{array}{l}\text { Net annual operating benefit } \\
\text { (annual operating benefit less } \\
\text { annual operating expense) }\end{array}$ & $\$ 49,095$ & $\$ 117,890$ \\
\hline l'ayout time for system (years) & 5.91 & 3.20 \\
\hline $\begin{array}{l}\text { Net present value of savings } \\
\text { over } 5 \text { years }\end{array}$ & $\$ 25,400$ & $\$ 137,220$ \\
\hline
\end{tabular}

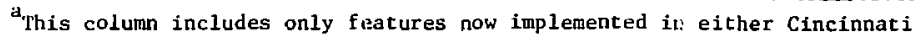
or Chicago.

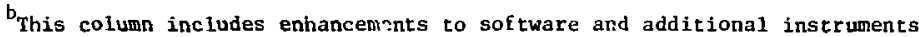
as indicated in Tables 2-3, 2-4.

$c_{\text {FTE }}=$ number of fuIl-time-equivalent employees. 
Is enough to require such additional Interface design costs. A breakdown of interface costs is giveil in Appendix 2 (Table 2-4).

- Software. Only those costs whlch are for requested improrements in the existing software system are included. In particular, new a:strumentation will necessarily cali for software changes or new modules to accommodate the change.

A bxeakdown of software costs is given in Appendix 2 (Table 2-3). The costs to modify existing computer programs written for the Data General computer in one EPA laboratory so as to adapt the programs to another Data General computer in the Annapolis laboratory are about $30 \%$ of the original costs to write the programs. Since the software that allows inceraction of such programs with a sample file control will be shared anong the EPA laboratories, only one-fifth of the total software deveiopment cost for standard SFC Is included in column 2 of Table 1 .

\section{Operation Costs}

The estimates of annual costs of maintalning the computer automation system are listed here, Including both hardware and software maintenance.

Data General offers a hardware maintenance contract at a monthly cost of about $1 \%$ of the inftlal cost of the hardware. We recommend this maintenance contract rather than the alternative of providing in-house hardware maintenance. The corresponding annual cost, or $12 \%$ of the conpucer and peripherals cost, is shown in Table 1 .

The software maintenance costs w1ll be fairly hfgh during initial usage, but w1ll soan taper off to low levels, to be replaced by modifications in output, calculations, etc., which will be requested by the users as they become experienced with the system. The software will be maintained initially by the supplier, by EPI Cincinnati, and by the users after acceptance of the system. In the system using only the existing soitware, monthly cost of malntenance is estinated at $1 \%$ of the initial cost of terminals plus interfaces. In order to use the systen effectively, the laboratory scient ist will have to develop certain skills. He must Interact with the syatem by entering data and control information on a cypewriter keyboard adjacent to the instrument. He must modify his previou: astual procedures and methods in order to accomodate this new "man-machine dialogue." He should be aware of what actions are necessary when an abnormal condition arises: If he types the wrong sample, or the computer detects or causes some sort of error. As he 
becomes famillar with the system over a period of a few monchs of pruduction uperation, the laboratory scientist will be able to spot and correct human, instrument, or computer malfunctions quickly himself or describe the symptoms of a more involved problem to the maintenance person. These skills are acquired by the laboratory sc entist in severai ways:

- Working visits to ERC Cincinnati for tutorial instruction before delivery of the system. This includes observation and use of a similar automated instrumert or procedure by the prospective new cllent, under guidance of a scientist who has acquired and is already usiug these skills.

- Remote access (via dial-up terminal) to an existing system for leacning BASIC and instrument program dialogues prior to system delfvery.

- Tutorial sessions given by the sutomation installacion cean during actual installation ( $1-4$ days per analyst).

- Self-study of the operational documentation provided with the system fur the use of each instrument.

As the laboratory scientist becomes more famlliar with the use of his dutsmited imstrument, he will probably want to modify and extend the capabilitiun of the sortware as follows:

- He may want to streamline the instrument setup and operation dialogue once he has bained ramiliarity with what the system needs to carry out his anitysis.

- Hc nay want to convert options provided with the delivered syster intu prigram constants to save clme, in the event that the itens are not thunged during a normal run.

- He may want to change the instrument data reduction algorithm to sccommudate a special analysis requirement or to foplement a new analysis method.

- He may want to change the structure or appearance of an obtput ropurt.

Whife the laboratory scientist will be able to make changes in input and output formats and procedures easfly using BASIC, there are certali: asks whicil wlll require gkllls that may not be easily developed in the laboratory :itaff. li one of the existlng stafl members cannot be trained, a new appluyec wll be required. This einployee's dutfes will include system responstbflicies such as maintenance and ipgrading of :

1. Hardware, including handling the computer vendor's service contract and maintaining the custom hardware. 
2. Instrunent control and applications software, incluciag assisting and ajvising the laboratory sctentists responsible for the individual instruments.

3. Sample file control functions, including tailoring reports and definition of file structure.

To the laboratory's unique needs this employee will have the primary responstbility for the computer system operation, including maintaining backup copies of all programs and imporzant files. HAs educational background wight be in electroniss, chemlstry, or computer science, but he must develop familiarity with all these fields. Appendix 6 amplifies on the manpower and sktlls problems.

These will be a higher level of software assistance provided by ERC Cincinnati. They will malntain and develop assembly language patches for tiw instruments, as well as serve as an exchange point and documentation center for software enhancements developed in or out of the Agency.

BENEFIT CONPARISONS

Each of the three alternatives considered in the preceding cost comparisons must be looked at critically to see whirh is best suited to the AFo laboratory: (1) no further automation, (2) adopting the Cincinnati automation system without change, (3) using the modifled Cincinnati system as proposed in Section 4 of this report. For each alternative we Iist advantages and disadvantages below.

Sumary of Advantages and Disadvantages

(1) No Further Automation -

This means the AFO laboratory as it stands, and includes any existing computer autonation that may have been applied previously.

\section{Advantages -}

- The large amount of capital funds that would have been spent for computer hardware with automation could instead be used for other purposes such as additional laboratory equipment.

- No time would need th be spent for training personnel in automation procedures. 


\section{Disadvantages -.}

- No reduction in man-hours spent in routine, uninteresting tasks.

- No reduction in calculational, transfer, and typographical errors.

- No lmmediate indication of faulty condftions.

- No easy way to produce consolidated reports, workload listings, and status reports.

- No automatic updating of́ statistical quality-control criteria.

(2) Existing Automation System.

This is the system presently running in two laboratories at the Environmental Kesearch Center in Cincinnat and in the Region " Central Reglonal Laboratory in Chicago. There woult be differences in hardware to take advantage of the latest i. els, but all the software would be the same as that presently running on one of these three existing systems.

\section{Advantages -}

- Reduction in man-hours spent in routine, uninteresting tasks.

- Reduction in calculational, transfer, and typographic errors.

- Irumediate indication of faulty conditions.

- Liof tware tested and debugged by others.

\section{Disadvantages -}

- Cost of the computer system and extra hardware.

- Time required to train personnel.

- Space required by computer system.

- Software not idealized for all functions of the AFo labcratory.

\section{(3) Modified Automation System (the Proposed System)}

This is the system escribed in Section 4. It uses the same hardware, but the sof tware has been modified to specifically fit the operation of the AFo laboratory, and to Include sample file control.

\section{Advantages -}

- Afl advantages of the second alternative except the last.

- Programs would be adapted to the particular needs of the AFO

laboratory.

- Easy creation of consolidated reports, status reports, and workload listing.

- Simplified operation of the instruments because of automated work plans operating from sample file control. 
- Automated updating of statistical quality-control criteria. Disadvantages -

- All disadvantages of the second alternative except the 1ast.

- Additional software cost.

- Debugglng would be slower as others might not be using the same software.

- Implementetion of report capability would be delayed, since tailoring of reports would be done by the local staff.

Estinating the Value of Benefits

(1) Instrument Time Savings

Each instrument to be automated has its own internal procedure and requirements for tending. Append $1 \times 3$ shows the identifiable actions that occupy a chemist' time and the best estimates of how his time is distributed among them. The estimates are based on Region III experience, and we can confixm that they fall within the range of reasonable times for such procedures. Tr..se are summarized in Table 2 .

\section{(2) Managerial Time Savings}

The savings due to management functions performed by the computer system, as defined in the AFo functional specifications for the sample file control, are derived from a model. This model is discussed in Appendix 4, and the benefits are summarlzed in Table 2 .

Although the AFO laboratory effort is expected to grow at $20 \%$ per year, this growth is not explicitly included in the benefit from automating the instruments. The impact of growth will be felt on botin automated and nonautomated analyses. For simplicity, and to estlmate conservatively, we assume the effort level of 50,000 determinations per year represents a mean ovar the 5-year payoff period. This number is applied to the management model. More detalled growth estimates do not significantly change the payout period shown in Table 1 .

\section{Quality Control Benefits}

EPA guidelines for quality control (Q⿱㇒) * call for a mininum of $10 \%$ of all analyses to be repeat standards, duplicate unknowns, spiked unknowms, and

\footnotetext{
*Minimat Requirements for a Water Quality Assurance Program, U.S. Environmental Protection Agency, Washington, D.C., EPA-440/9-75-010 (1975).
} 
other similar analysis checks. The goal is to raise this to $20-40 \%$. Under the pressure of sample volume it is aJ too easy to overlook these QC samples. With automation they are handled at very little extra cost, only the small additional analyst time for pipetting the QC test samples, which is more than offset by the savings the computer provides in handling the complex statistical calculations that have to be carried jut for good quality control. Thus, since the present staff time on the instruments to be automated is 4.72 FTE (fulltime-equivalent employees), $30 \%$ of this, or 1.42 FTE, will be saved by automation. An additional 0.5 FTE is presently devoted solely to collectiug and reporting QC, making a total saving of 1.92 FTE or $\$ 67,000$ per year directly attributable to quality control.

\section{Operating Benefits and Payout}

The manpower savings in Table 2 apply to the full automation system for the AFI) laboratory as proposed in Section 4. The proposed AFo system owes its increased manpower savings and increased one-time costs mainly to the following three factors:

1. The inclusion of sample file control.

2. Automation of the CSM-6. The manpower saving of 0.75 attributed to automating this instrument is gained at a cost of $\$ 14,000$ in software and $\$ 14,200$ in hardware.

3. Use of the industrial chart method. A fractional benefit of 0.2 out of the 0.5 manpower saving estimated for automating the managerial aspects of quality control is attributed to use of the industrial chart method at AFo. This preferred method may well be of general Interest for other laboratories in the EPA.

While no benefit is assigned to other, less significant changes to the Cincinnati system, their importance to user acceptance should not be winimized, and mos of them may also be useful to other EPA laboratories as well.

The annual operating benefit for the proposed system is the 4.97 total shown in Table 2, whereas the benefit assigned to the present systen without upgraded software is the 1.95 subtotal for Instrument automation alone. The beneflts of 1.95 and 4.97 are carried to Table $l$.

The operating benefits are converted to a dollar value on the basis of the mean manpower costs for the payout period (Appendix 3) so that a direct comparison to costs can be made. The net annual benefit is the operating benefit less the annually incurred cost. 
The payout time is calculated on the basis of $10 \%$ per annum discounting, compounded annua11y. Given the ratio of initial cost to annual benefit, $\mathrm{c} / \mathrm{B}$, the payout time, $T$, is estimated as

$$
T=-\ln (1-I \cdot C / B) / \ln (1+I)=-\ln (1-0.1 \mathrm{C} / \mathrm{B}) / 0.09531 \text {, }
$$

where $I$ is tha discount rate, $0.1 / y r$.

The net benefit realized in five years is estimated as

$$
B_{5}=B \cdot\left[1-(1+I)^{-5}\right] / I-C=3.791 B-C .
$$

Tabie 2. Sumary of estimated savings in manpower requirements at the AFo laboratory with the proposed automation system.

Manpower saved by replicate instrument automation:

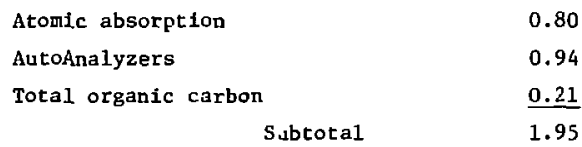

For full automation add:

$$
\begin{array}{ll}
\operatorname{css}[-6 & 0.75 \\
\text { Industrial chart QC method } & \underline{0.20} \\
\text { Subtotal } & 0.95
\end{array}
$$

\begin{tabular}{|c|c|}
\hline Managers' reports and projections & 0.73 \\
\hline Workload lists & 0.21 \\
\hline Sample summary reports & 0.32 \\
\hline WhRS's and form letters & 0.19 \\
\hline Update records & 0.32 \\
\hline Quality control & 0.30 \\
\hline Subtolal & 2.07 \\
\hline
\end{tabular}

Manpower saved by automated management functions:

Total manpower saved by full automation

Note: The benefit of 1.92 men attributable to improved quality assurance is included in the above. It is not clearly shown because of the different mithodology used to prepare this summary. 


\section{Impact of the Proposed System on AFO Laboratory Operations}

Our general impression is that the AFO people are ready and willing to convert to a more automated system. The number of samples that must be handled and the number of reports to be written are a great incentive. The automation will be done in a stepwise and logical fashion, making all reasonable efforts not to disrupt operations more than absolutely necessary. Initially, data will be taken in the conventional way in addition to the computer oulput. As confidence grows in the automated system, the conventional readouts can be phased out.

The recommended system is designed so that modifications to operating procedures can be made by the chemists themselves. Malntenance of the operating system's sof tware and hardware will be provided by the manufacturer of the computer.

Further expansion of the Annapolis Field office would require acditional automation. Many new instruments now come with their own minicomputer or microcomputer that should logically be connected to the sample file control system. The recommended system has the flextbility to accomnodate such developments. 


\section{Appendix 1.}

\section{Guidelines Followed in Evaluating Automation Systems}

1. A high-level programming language. We have chosen Dartmouth BaStc, as extended, as the most destrable programing language to use in the EPA laboratory environment. Invariably, modifications aro needed in the computer programs to meet future laboratory requirements. If such changes are difflcule to nake, the operator will either live with less than optimum conditions or revert to manual operation, thus undolng many of the benefits that automation was to provide. Of the various high-level languages, BASIC has proven to be the most widely available, being supported by most of the major minicomputer vendors. FOCAL, which was introduced by Digital Equiprent corporation, 15 no longer supported by chem. FCRTRAN is a slightly more powerful language than BASIC, and usually faster in execution, but the BASIC interpreter makes program development and modification easier and much faster for the cheralst, who can do 1t while other instruments operate as usual.

Modification of FORTRAN programs requires stoppling the compuler, and restarting it with the new program. This can happen many times as a new program is debugged (perfected), which would destroy normal laboratory procedures.

BASIC is now being taught in many high schools and colleges als the language of preference for the occasional computer programer. Nthough there are some differences among vendors in the way BASIC is used, these are in the extensions to the language and are easily understood. Standards are presently beling developed by a comattee of the American National Standards Association. Another strong point of BASIC is that it can be modified on-line and tested immediately. This means that a simple change in calculations or instrument operation can be made directly by an analyst in a very short period of time on the order of 15 minutes. Although interpreted codes like BASIC run more slowly than compiled codes like FORTRAN in most syscems, this will not be a disadvantage in the system we propose, because the gain from BASIC's flexibllity will more than offsez the slower runing time.

2. Fleld-proven operating system. We feel that no new or prototype operating system should be considered. Our observation is that new systems have many "bugs" in them. Often, toc, prototype systems are announced with the promise of early delivery, and then the manufacturer finds he cannot deliver them unt1l months after promised. To avold such problems, only operating 


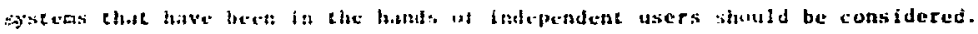

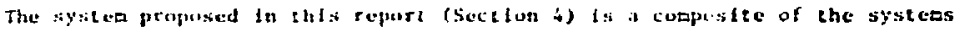

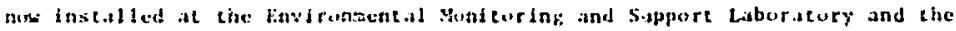

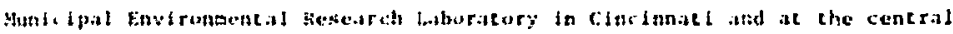

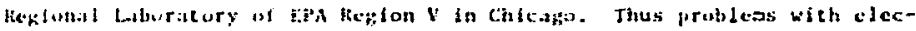

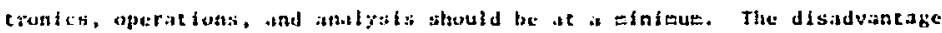

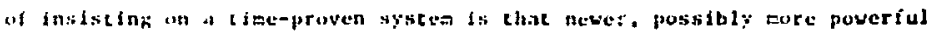

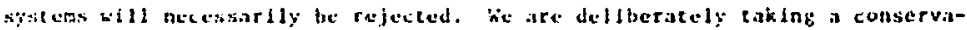
Elve \#aition.

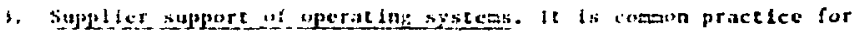

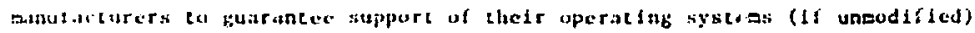

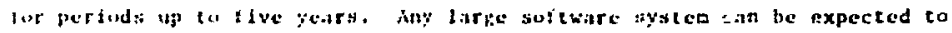

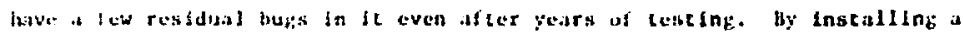

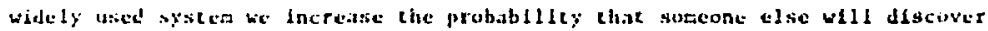
the buks, and thise the manufacturer will it the before they cause probleas lor tis.

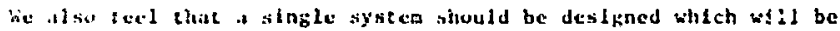
versilt le enoufle to watisy che differlng teeds of users in different laboras torita. It Hik sere to set up a ainicogputer systeos group to develop and mintain a unique, speclat-purpose ogerating system for tes water qualiey

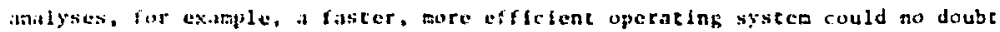
be witcen. It would be very diffleult to change, however, ind would require the asifstince of the systems aroup for most modifleatfons, Such special uptriting syscens now on the mirket are exeplifled by the finnigin GC/MS, Hewlett-lackir-1, Perkin-Elmer, and Vartan cic systems. These are singlepurpose systers and vork very well; but they are proprlec.ry, asking any changes imposstble without the ald oi the original suppiler. he feel that rot sliould not put itsedf in the hitnds of a unlque supplier, but rathet should adopt systems that tan be madifled by the users.

In the particular case of tha cic and cis/As systems, hubever, we feel that EPA should continue with thesc existlng cested systems, whilh are costeffective as they stand, and couple the otoput frot these spectil-purpose computers inta the sample file control system.

4. Multi-user, mult1-appl lcation, real-time, efme-share. There art a number of potentially attractive systems which lack one or tore of these characteristics. The operating system must be designed to handle several uscrs and several instruments simultineously while giving each at least the' 
appearance of a dedlcated computer. A time-shared system can do this while providing for the sharing of expensive perlpherals such as line printers and magnetic tape. A time-shared system also ives the option of adding additional instruments to the systen inexpensivejy. With individual computers, an additional computer has to be purchased with each new instrument. A disadvantage wi the time-shared computer is that fallure of the single shared computer ivrces all users back to manual methods.

5. Data management language. The computer system selected should provide the ability to easlly reprogram the names and relationships of all the data. At the outset this ability alds in the programming of the sample file controller. But most important, it will prevent obsolescence in the not unlikcly event of new management requirements. For example, making a change In anafytical reporting prucedures or adding hiological assay categories to the existing systems should be easily possible for the user by means of only simple reprogranuing procedurts.

6. Rapid response time. Because of human impatience, worst-case computer response the from the issuing of a keyboard command must be no more than at tew seconds. After about 10 seconds, most users become irritated. Fur automated data collection, worst-case times from the receipt of a "data is ready" Indication to data collection action must be less than $200 \mu s$.

7. Instrument input/output handlers. It would be advantageous if the computer vendor provided sof tware to handle data acquisition from instruments, cilculation, and reporting functions. No vendor known to us now supplies soitware for all the particular instruments we have been asked to consider. Custom algorithms and data acquisition and control programs must be provided. The computer system vendor must a'low these algorithms to be simply implemented with a clear description of how to pass to and from BASIC and how to use the operating system for input and output of instrument data.

8. String manipulation capability. For the simplest and most natural interaction between operator and computer for efficient information flow betwern fata and reports, the system must have the ability to handle alphanumeric strings. If this feature is not provided by the manufacturer it will have to he added by the system implementer.

9. Swapping. In order to make the most efficient use of core storage, effective program swapping must be available. This implies that run, swap-in, and swap-out areas must be concurrently active. Virtual systems using paging have been proposed as an alternative. For laboratory automation, however, we 
do nut feel that the art of virtual. memory has advanced to the same leveld ul effectiveness as progran swaping systems. At present, virtual meaury systers require careful tailoring of the programs tu avoid excessive page swappin:s. If programs are to be modified by the chomists, the burden of tajlorjng the programs cannot be placed on the chemists.

10. Chaining and overtays. The ability tu chain programs and to overluy segments is imperative. The alternacive is to have all programs crire-contained, which would require excessive core storage.

11. Files. Data files will be stored on the disk for later manipulation and development of new analysis methods by the chetnists. These files must be accessible from both the machine language and BASIC level code, since some files will be built by the machinc level code and used by the BASIC code.

12. Foreground-background operatiun. This feature is desirable for sample file control and report preparation. The instiument control programs must run in real time, along witt their operator prompts, Calculation routines, sunmiry reports, etc., do not require real-time capability, and so can be run in a background mode, using otherwise idle time and increasing the overall eliitiency of system use.

13. Anitog-to-digital converter. Most data acquisition will be done by a multiplexed $\Lambda / b$ converter. To provide for future growth this converter should be easily expandable to at least 32 channels. Instrumant interfaces will convert the data to high-level analog form ( \pm 10 volts) for input to the AD converter. This will permit the inclusion of additional instruments in the cuture with a minimum of difficulty. At this time individual digitizers on each instrument are not an economical alternative.

14. kandom-access mass scorage. The computer must have storage for large amounts of sample data and extensive libraries of special-purpose calculational routints. These should be available on-line for maximum effective-ness, rather than being on special magnetic tapes that have to be physically renoved from a file and hung on a tape deck each time they are used. We propose enough storage to keep at least one month's worth of data available at all times, together with the search routines necessary for analysis of $i^{\prime}$ it data by the analysts, engineers, and managers. This will allow for such functions as checking for dilutions on previous samples from the same site, addition of data from long term tests, and addicion of results from analysi; put of during peak worklonds. 
A large disk pack is the pertpheral devlce thit best meess these needs, although a moderace-gize disk supplemented by several on-line magnet 1 : $t$ alpus might be an economical alternative.

15. Boorstrap loader. If the system is to be used effectiveiv withut a professional data-processing staff, there oust be a hardwired boctstap loader enabling the occasional user to reload the systen after power failures and similar catastrophes. This feature is also very viluable during the inltial impiemen at ion and debugging, and when new Instriments are baing incorporated into the system.

16. Real-time clock. A real-time clock whose rate is an integral multiple of $60 \mathrm{~Hz}$ is needed. This will be used primarily for ciminf the sampling of data from instruments.

17. Multiple terminals. An analyst's acceptance of the computertzed system is strongly influenced by his abllity to rontrol it and to know what is happening all the time. There should be a terminal (either a hard-copy cypewriter or CRT screen) at each active analytical instrument or group of instruments. This allows initlation of runs, display of daca as calculated, and display of diagnostic messages such as out-of-range concentrations. The operator need not be at the terminal at all times, but he must have immediate access to it so he can verify proper operation.

18. Printer. A medíum-speed printer is needed for rapid printout of reports. Users will not want to wait for slow typewriter-style printers, espectally for such long lists as work loads. One printer woisld be shared by all users.

19. Magnetic tape, IBM-compatible magnetic tape is needed for three functions: (1) to store the entire data files on a routine (approximately weekly) basis to covir catastrophic system failures, (2) to transmit properly formatted data to the STORET systen, and (3) to exchange programs between laboracories.

20. High-speed paper tape reader. This is necessary to load diagnostics programs. It is primarily a backup systeln to the disks and magnetic tape.

21. Software transpor:ability. Software transportability among the EPA laboratories is a primary goal of the Pilot Laboratory Automation Project. The low cost estimated for the AutoAnalyzer and atomic absorption software is dependent upon the use of exlsting software for these instruments. Likewise, the cast for interfaces include only incremental production costs, since the engineering costs were paid in designing the previousiy installed systems. 


\section{Appendix 2. \\ Costs of Hardware and Software}

In this appendix we give costs of hardware and suitware as well as data storage requirements for the AFO system. Table 2-1 compares the cost of the central romputer hardwar. and peripherals for the proposed Afo system and the Chicigo system. Table 2-2 summarlzes the estimated datamstorage requirements fur the proposed AFG system. Table 2-3 glves estimated software costs for application programs for the instruments to be automated in the Afo system, and fible 2-4 hlves hardware costs for automating these instruments.

Table 2-1. Hardware costs for central computer and peripherals for the proposed AFO system. The Eclipse $\mathrm{C} / 300$ computer is a Data General product. Costs figures are discounted.

\begin{tabular}{|c|c|c|c|}
\hline & $\begin{array}{l}\text { Minimum } \\
\text { system }\end{array}$ & $\begin{array}{l}\text { Kecommended } \\
\text { system }\end{array}$ & $\begin{array}{l}\text { Maximum } \\
\text { system }\end{array}$ \\
\hline $\begin{array}{l}\text { Computer main frame with } 65 \mathrm{~K} \text {-word core, } \\
\text { real-time clock, memory allocation } \\
\text { and protection }\end{array}$ & $\$ 38,376$ & $\$ 38,376$ & $\$ 38,376$ \\
\hline Additional $65 \mathrm{~K}$ core & - & - & 19,352 \\
\hline Fixed-head disk & 10,045 & - & 10,045 \\
\hline Moving-head disk & 8,938 & 31,760 & 31,760 \\
\hline Magnetic tape & 7,380 & 7,380 & 13,712 \\
\hline LIne printe: and interface & 5,648 & 9,812 & 9,812 \\
\hline Paper tape reader and interface & - & 1,640 & 1,640 \\
\hline Analog-to-dlgital converter system & 5,354 & 5,354 & 5,354 \\
\hline Rack & 1,900 & 2,850 & 2,850 \\
\hline Software from Data General & 1,000 & 1,000 & 1,000 \\
\hline Totals & $\$ 78,641$ & $\$ 98,172$ & $\$ 133,901$ \\
\hline
\end{tabular}


Table 2-2. Estimated data-storage requirements (in 8-bit iytes) for the proposed AFO system, based on 100 samples and stindards.

\begin{tabular}{|c|c|c|c|c|c|}
\hline Instrument & $\begin{array}{l}\text { BASIC } \\
\text { language } \\
\text { prograta }\end{array}$ & $\begin{array}{r}\text { Data } \\
\text { tiles }\end{array}$ & $\begin{array}{l}\text { Nimber } \\
\text { of files }\end{array}$ & Tutal & $\begin{array}{l}\text { Assembly } \\
\text { language } \\
\text { palch }\end{array}$ \\
\hline Atomic absorption & 25,000 & 25,600 & 2 & 101,200 & $30000^{b}$ \\
\hline Technfcon Autodnalyzer I & 40,000 & 115,200 & 4 & 500.800 & $\$ 000$ \\
\hline Technicon AutoAnalyzer II & 40,000 & 115,200 & 5 & 616,000 & $5000^{b}$ \\
\hline Technicon AutoAnalyzer CSM-6 & 60,000 & 230,400 & 1 & 290,400 & - \\
\hline Beckman cotal organic carbon & 25,000 & 271,360 & 1 & 296,360 & - \\
\hline \multirow[t]{2}{*}{ Sample flle control } & 200,000 & $100,000^{c}$ & 1 & $2,400,000$ & - \\
\hline & \multicolumn{3}{|r|}{ Total } & $4,204,760$ & \\
\hline
\end{tabular}

${ }^{a} A 11$ BASIC programs are broken into parts each no longer than $19 \mathrm{~K}$ byces, so as to fit in $64 \mathrm{~K}$ words of core along with the oparating systers.

${ }^{b}$ Core-resident data. The first two entries service all other instruments.

'One day's worth of data. Provision will te made to store at least one month's worth of data.

Table 2-3. Estimated software costs for applications programs for the instruments and tunctions to be automated in the AFO system.

\begin{tabular}{lc}
\multicolumn{1}{c}{$\begin{array}{l}\text { Instrument or } \\
\text { function }\end{array}$} & $\begin{array}{c}\text { Upgrading costs } \\
\text { to meet proposed } \\
\text { AFo system } \\
\text { requirements }\end{array}$ \\
\hline $\begin{array}{l}\text { Atomic absorption } \\
\text { (PE305B, V-AA6) } \\
\begin{array}{l}\text { AutoAnalyzers } \\
\text { (I, II, CSM-6) }\end{array}\end{array}$ & $\$ 7,000$ \\
$\begin{array}{l}\text { Carbon analyzer } \\
\text { Sample file control }\end{array}$ & 14,000 \\
\end{tabular}

${ }^{2}$ It is assured that an agency-wide SFC system will be developed based on agency-wide specifications now being developed under the ausplces of MIDSD. About $20 \%$ of the estimated development costs have been included in this feastbility study, with the assumption that this SFC will be used in at least four other labcratorles. 
Titble: 2-4. Fst imated bardwarce costs for dutorating the AFo instruntents.

\begin{tabular}{|c|c|c|c|c|c|}
\hline & $\begin{array}{l}\text { Number } \\
\text { of units }\end{array}$ & $\begin{array}{l}\text { Design } \\
\text { cost }\end{array}$ & $\begin{array}{l}\text { Cost to build, } \\
\text { debug. assembla }\end{array}$ & $\begin{array}{l}\text { Cost of } \\
\text { parts }\end{array}$ & $\begin{array}{l}\text { Tutal } \\
\text { iost }\end{array}$ \\
\hline ciencral incerface & 1 & 0 & $\$ 4,120$ & 53,200 & 57.320 \\
\hline Autonnalyzer 1,11 & 9 & 0 & 15,900 & 2,700 & 16,600 \\
\hline Aucoinalyzer CSH-6 & 1 & $\$ 11,800$ & 1,900 & 500 & 14,200 \\
\hline Sample wheel & 1 & 0 & 2,800 & $80 n$ & 3,600 \\
\hline MA JOSH & 1 & o & 910 & 400 & 1,310 \\
\hline M Varian Mh & 1 & 11.800 & 910 & 200 & 12,910 \\
\hline Total carbon & 1 & 0 & 1,060 & 200 & 1,260 \\
\hline \multicolumn{2}{|c|}{ Totils } & $\$ 23,600$ & $\$ 27,600$ & $\$ 8,000$ & $\$ 59,200$ \\
\hline
\end{tabular}




\section{Appendix 3. \\ Instrument Time Savings as a Result of Automation}

We have adopted a model in which the total time needed for any one Instrumental sample analysis, $t_{s}$, is broken into a number of increments which are then summed and modified by the following equations:

$$
t_{s}=p+(1 .+f)(l+1+c)+f d
$$

where

$$
\begin{aligned}
& t_{s}=\text { total chemist time needed for each sample, } \\
& P=\text { time for preparation of sample and } l o g \text { book, } \\
& \ell=\text { time control to } l o g \text { and introduce sample, } \\
& 1=\text { chemist time needed tending instrument, } \\
& c=\text { time needed to calculate and transcribe results, } \\
& d=\text { time taken for dilution, } \\
& \mathbf{E}=\text { fraction of samples diluted; }
\end{aligned}
$$

and

$$
e=t_{s} q r \frac{H}{H-T_{b}} \text {, }
$$

where

$$
\begin{aligned}
e= & \text { the effective chemist time taken per sample, } \\
t_{s}= & \text { total time calculated by the previous formula, } \\
q= & \text { quality assurance factor (total } \\
& \text { determinations/unkncwn), } \\
r= & \text { fraction of samples retested, } \\
H= & \text { tlme of a work session (usually } 8 \text { hours except where } \\
& \text { the average weekly load can be completed in less than } \\
& 8 \text { hours; it is assumed the instrument must be operated } \\
& \text { at Ieast once a week to prevent delay in reporting } \\
& \text { results), }
\end{aligned}
$$


$T_{b}=$ time to set up instrument at the beginning of each work session, shut it down at the end, and run standards.

Table 3-1 sutmarizes the manpower savings expected from automation of the various instruments, as calculated wtth the above model. Tables 3-2 through 3-5 give the results for the various instruments to be automated. Times given in the columns headed "present techniques" are cousistent with values received from Jim Marks and orc Villa of AFo. Times given in the columns headed "automated techniques" are our estimates of the times needed after automation. 
Taole 3-1. Sumary of manpower savings calculated to result from automation.

\begin{tabular}{llcc}
\hline \multicolumn{1}{c}{ Instrument } & \multicolumn{3}{c}{ Man-years per year } \\
\cline { 4 - 5 } & Present & WiLä automation & Savings \\
\hline AutoAnalyzer cSM-G & 1.39 & 0.64 & 0.75 \\
Atomic absorption spectrophotometers & 1.36 & 0.56 & 0.80 \\
AutoAnalyzer I & 1.43 & 0.49 & 0.94 \\
Total organic carbon analyzer & 0.54 & 0.33 & 0.21
\end{tabular}

Table 3-2. Estimated savings with automation for the Technicon AutoAnalyzer CSM-6, assuning four channels working.

Item Symbol ${ }^{a} \begin{gathered}\text { Present } \\ \text { techniques techniques Difference }\end{gathered}$

Preparation of sample

Log and introduce sample

Instrument time for chemist

Calculate and transcribe results

Dilution of off-scale samples

Fraction of samples diluted

Total chemist time per

$$
\text { analysis }
$$

Retest factor

Qualicy control factor

Setup and shutdown time per session

hours per work ression

Effective chemiat time per analysis

Number of samples per cheratist-day

Sample load assumed per year Chemist-days needed per year Chentst-years needed per year

$\begin{array}{llll}p & 0.60 \mathrm{~min} & 0.60 \mathrm{~min} & 0 \\ \ell & 0.77 \mathrm{~min} & 0.50 \mathrm{~min} & 0.27 \mathrm{~min} \\ 1 & 1.5 \mathrm{~min} & 0.4 \mathrm{~min} & 1.1 \mathrm{~min}\end{array}$

$\begin{array}{lllll}\text { c } & 1.0 \min & 0.0 & 1.0 \mathrm{~min} \\ \mathrm{~d} & 5 & \mathrm{~min} & 4.8 \mathrm{~min} & 0.2 \mathrm{~min} \\ \mathrm{f} & 0.15 & 0.15 & 0\end{array}$

$\begin{array}{llll}t_{s} & 5.11 \text { min } & 2.36 \mathrm{~min} & 2.75 \mathrm{~min} \\ \mathrm{r}^{\mathrm{s}} & 1.2 & 1.2 & 0 \\ \mathrm{q} & 1.2 & 1.2 & 0\end{array}$

$\begin{array}{llllll}\mathrm{T}_{\mathrm{b}} & 2.5 & \mathrm{hr} & 2.5 & \mathrm{hr} & 0 \\ \mathrm{H}^{\mathrm{b}} & 8 & \mathrm{hr} & 8 & \mathrm{hr} & 0\end{array}$

e

$10.71 \mathrm{~min} \quad 4.94 \mathrm{~min}$

$5.77 \mathrm{~min}$

\begin{tabular}{ll}
44.8 & \multicolumn{1}{c}{97.1} \\
14,000 & 14,000 \\
313 & 144
\end{tabular}

1.39

0.64
52.3 samples 0 169 days

0.75 year

$$
t_{s}=p+(1,+f)(l+1+c)+f d, e=t_{s} r q \frac{H}{H-T_{b}} .
$$

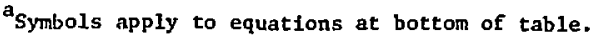


Table 3-3. Estimated savings with automation for atomic absorption analysis.

Item

Log and Introduce sample

Instrument time for chemist

Present

Automated

Symbol $^{a}$ techniques techniques

Difference

Calculate and transcribe results

Dilution of off-scale samples

Fraction of samples diluted

Total chemist time per sample

Retest factor

Quality control factor

Setup and shutdown time

per session

Hours per work session

Effective chemist tine

$$
\text { per sample }
$$

Number of samples per

$$
\text { chemist-day }
$$

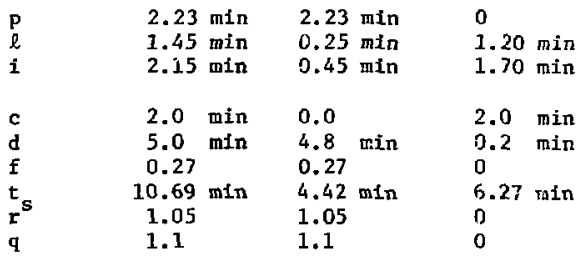

Sample load assumed per year

Chemist-days needed per year

Chemist-years needed per year

$\begin{array}{rrlrll}\mathrm{T}_{\mathrm{b}} & 30 & \min & 30 & \min & 0 \\ \mathrm{H}^{\mathrm{b}} & 8 & \mathrm{hr} & 8 & \mathrm{hr} & 0\end{array}$

$$
t_{s}=p+(1+f)(n+i+c)+f d, e=t_{s} r q \frac{h}{H-T_{b}} .
$$

${ }^{a}$ symbo1s apply to equations at bottom of table. 
Table 3-4. Estimated savings with automation for Technicon AutoAnalyzer I (total phosphate, total KJeldahl nitrogen).

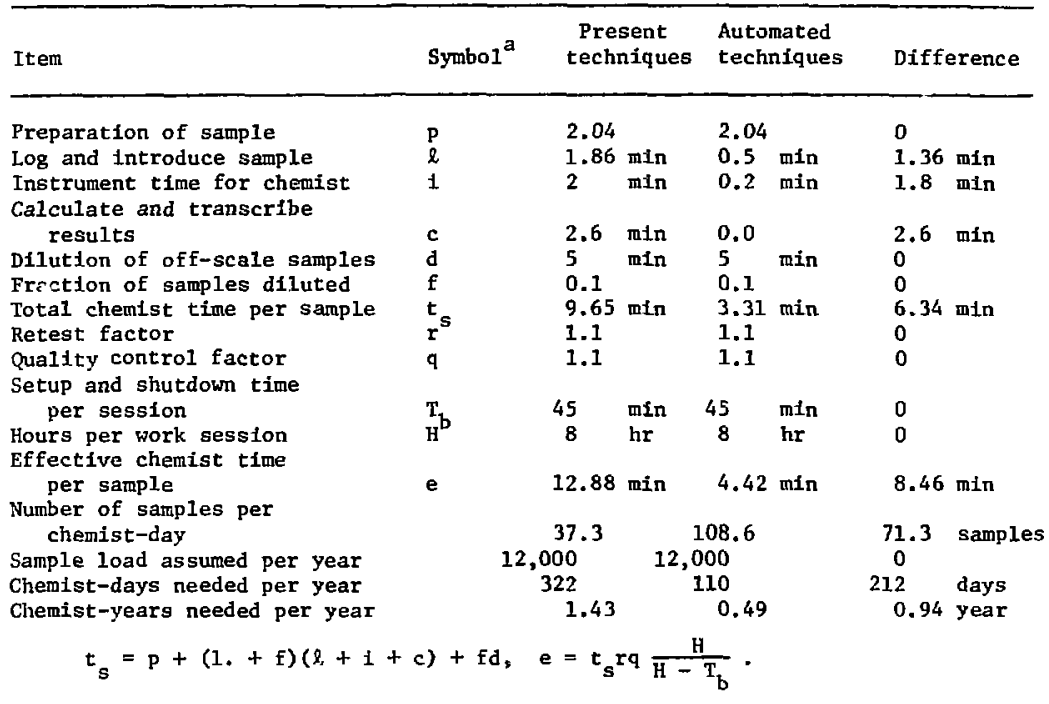

${ }^{a}$ Symbols apply to equations at bottom of table. 
Table 3-5. Estimated savings with automation for Beckman total organic carbon analyzer, assuming five runs per sample.

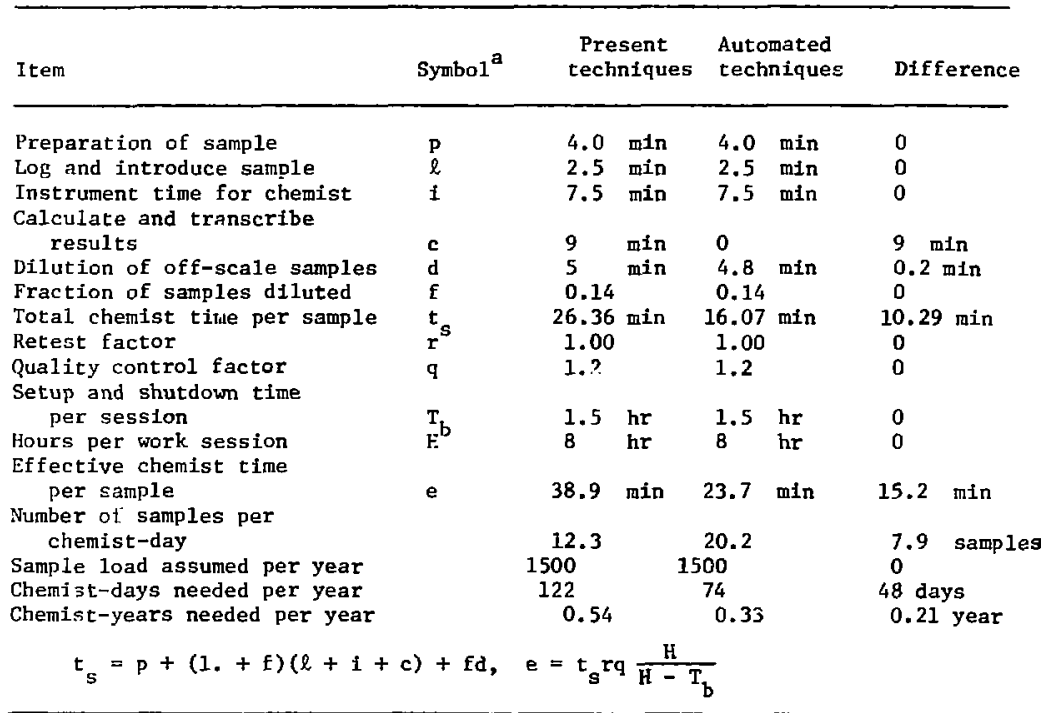

a Symbols; apply to equations at bottom of table. 


\section{Appendix 4. \\ Manpower Savings as a Result of Automation}

\section{SAMPLE MANAGEMENT SAVINGS}

We have chosen to develop a linear model for sample management operations. The results for the model are validated against the sample management estimates for the Annapolis Field office.

We first identify the sample management functions as follows:

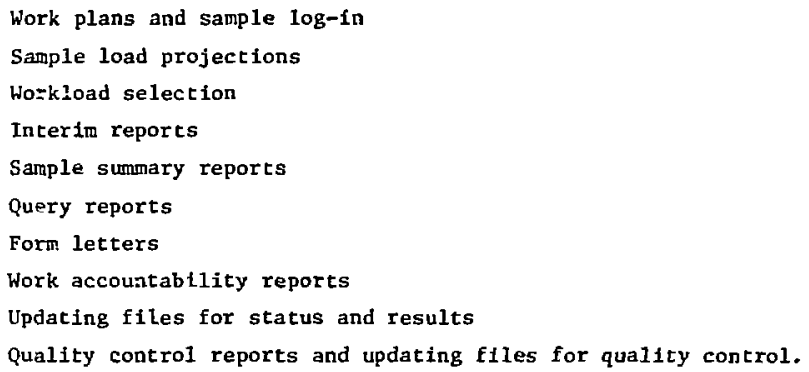

These items correspond to the functional description of the sample file control (SFC) system.

Each of the functions is considered in terms of how much effort is expended with and without sample file control. Each function is modeled as some number of transcriptions, filing and retrieving of files, and data checking or tallying. Times for the varfous processes are estimated; for example:

$\begin{array}{ll}\text { Transcriptious - } & t=6 \mathrm{sec} \\ \text { File and retrieve - } & f=4 \mathrm{~min} \\ \text { Checking - } & c=3 \mathrm{sec}\end{array}$

These numbers include the time for correcting transcription errors.

In ultinately converting the time in minutes to man-years, a 7-hr day is assumed to allow for human overhead (efficiency), and a 250-day work-year: is used. The factor is 


$$
k=\frac{1}{60 \times 7 \times 250}=9.52 \times 10^{-6} \text { man-year/minute. }
$$

For the purposi of counting the number of transcriptions or checking, only a portion of the information in the SFC is used for a given report. The following average maximum numbers of each data type are obtained from the functional description of the sample file:

$$
\begin{array}{lr}
\text { data that describe the study - } & 8 \\
\text { data that describe the sample - } & 15 \\
\text { data that describe the analysis - } & 9
\end{array}
$$

For the purpose of counting the number of reports per year, we obtalned the Following estimates from the Annapoits Field office:

$\begin{array}{llc}\text { Report type } & \text { Frequency } & \begin{array}{c}\text { Annual frequency } \\ \text { used In the model, N }\end{array} \\ \text { Workload list } & \text { Daily } & 250 \\ \text { Interim, short } & \text { Dally } & 250 \\ \text { Interim, Long } & \text { Weekly } & 50 \\ \text { Study status } & \text { Weekly } & 50 \\ \text { Query } & \text { Twice daily } & 500 \\ \text { Sample load } & \text { Tri-weekly } & 15 \\ \text { Form letters } & \text { One/study } & 100 * \\ \text { Summary sample } & \text { One/study } & 100 \\ \text { WARS } & \text { Monthly } & 12\end{array}$

\footnotetext{
* The number of studies is complicated by quarterly repeats of the same study, fiscal year accounting, etc., and was estimated at Annapolis to be as many as 150-200 annually.
} 
We take rounded figures for the key paraneters describing the level of effort at the AFO:

$\begin{array}{lr}\text { Number of determinations per year, D } & 50,000 \\ \text { Number of samples logged per year, S } & 2,500 \\ \text { Number of studies (projects) per year, P } & 100 \\ \text { Number of samples per study, S } & 25 \\ \text { Number of determinations per sample, D } & 20 \\ \text { Mean tfme to complete study, T } & 10 \text { days }\end{array}$

On the following pages the assumptions made in developing the benefit models for each managerial function are discussed. In general, the most efficient manual record-keeping and filing formats are assumed, and the analyses are assumed to be managed in such a way as to minimize paperwork, even though In fact this is not possible if the samplrs have a linited life. The effort required for the automated reports is assumed negligible, although some manual effort is required to get 11neprinter output. All benefits are therefore net benefics. Following the detall of the models, the derived benefits are summarized in Table 4-1, and carried to Table 2 (in Section 5 of the report).

The annual growth of the sample effort has been estimated by 0 . Villa of $\mathrm{AFO}$ to be $20 \%$. For simpliclty, and to estimate conservatively, we assume the effort level of 50,000 determinations a year represents the mean over the 5 year period of amortization.

\section{Nork Plans and Sample Jog-In}

The Information about the samples and project must be provided to the sample file by keying-in data, whether the sample file is automated or not. The automated procedure should be at least as easy as the manual method, in which preformatted sheets and ditto marks ease the entry of data. No net benefit is clatmed for the functions of work plans and log-in.

\section{Sample Load Projections}

Assume: $\quad$ For every parameter, for one month of planned samples, check four Items: date, subelement number, status, and analysis. 
Table 4-1. Summary of net benefits derived from a model for the managerial functions.

\begin{tabular}{lc}
\hline & Net benefit (man-years) \\
\hline Work plans & 0.00 \\
Sample log-in & 0.00 \\
Sample load projection & 0.13 \\
Workload lists & 0.21 \\
Interim reports & 0.56 \\
Sample summary & 0.32 \\
Query reports & 0.04 \\
Form letters & 0.09 \\
Work accountability & 0.10 \\
Update status and results & 0.32 \\
Quality assurance & Total \\
\hline
\end{tabular}

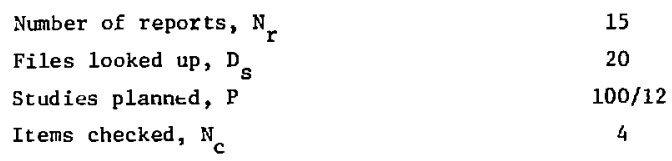

$$
\begin{aligned}
\text { Benefit } & =\left[D_{s} f+P S_{p} D_{s} N_{c} c\left(\frac{1}{60}\right)\right] N_{r} k \\
& =\left[20 \times 4+\frac{100}{12} \times 25 \times 20 \times 4 \times 3\left(\frac{1}{60}\right)\right] 15 \times k=0.13 \text { man-year. }
\end{aligned}
$$

Workload Selection

Assume: For every active study and every sample, the parameter and status are checked $\left(\mathrm{N}_{\mathrm{C}}=2\right)$. If the status is "nnt done," transcribe the limits, sample number, and due date $\left(N_{t}=3\right)$. Assume two differenc parameters are run each day for the 10 days $\left(T_{p}\right)$ required to complete the study. 
Projects active on any given day, ? 4

Number of parameters run per day, $\mathrm{D}_{\mathrm{S}} / \mathrm{T}_{\mathrm{p}} \quad 2$

(implies 200 deterninations/day)

Number of reports, $\mathrm{N}_{\mathrm{r}} \quad 250$

Files looked up, $\mathrm{D}_{\mathrm{S}} / \mathrm{T}_{\mathrm{p}}$

Checks, $N_{c}$

Transcriptions, $\mathrm{N}_{\mathrm{t}}$

$\begin{aligned} \text { Benefics } & =\left[D_{s} f+P S_{p} D_{s}\left(N_{c} c+N_{t} t\right)\left(\frac{1}{60}\right)\right] N_{r} k / T_{P} \\ & =\left[20 \times 4+4 \times 25 \times 20(2 \times 3+3 \times 6)\left(\frac{1}{60}\right)\right] 250 k / 10=0.21 \text { man-years. }\end{aligned}$

Interim Reports

Short Reports

Assume: For every active study, for every sample, list the sample number and parameter status. Also transcribe the study and subelement number.

Number studies active, on a given day, $P \quad 4$

Number of reports, $\mathrm{N}_{\mathbf{r}} \quad 250$

Filles looked up, $\mathrm{N}_{\mathrm{f}}$

1 (assurnes a

special file).

Benefit (short report) $=\left[f+P\left(2 t+S_{p}\left(t+D_{s} t\right)\right) / 60\right] N_{r} k$

$=[4+4(12+25(6+20(6))) / 60] 250 k=0.51$ man-year.

\section{Long reports}

The long interim report calls for a sample description to be transcribed in addition to the above, but fewer reports, $\mathbb{N}_{\mathbf{r}}=50$.

$$
\begin{aligned}
\text { Benefit (long report) } & =\left[f+P\left(2 t+S_{P}\left(2 t+D_{S} t\right)\right) / 60\right] N_{r} k \\
& =0.11 \text { man-year. }
\end{aligned}
$$

Because the dafly reports are avallable and collated, the claimed benefit for the long report will be less. We estimate $50 \% 1$ ess, or 0.05 man-year. 


\section{Week 1y Reports}

Assume: The weekly staius report lists the subelement, citla, and status of each active study. The checking of each sample status is included. Number of reports, $\mathrm{N}_{\mathrm{r}}=50$.

Benel $\perp$ (weekly) $=\left[f+p\left(3 t+D_{s} c\right) / 60\right] \mathrm{N}_{r} k=0.005$ man-year.

\section{Sample Summary Reports}

Assume: For one study and all samples and parameters, 1 ist the results. List study description, sample descriptions (14 items) and parameter units, analyte code and STORET number plus the result or status. Include column header transcriptions.

$\begin{array}{lr}\text { Studies, } P & 1 \\ \text { Number of reports, } N_{r} & 100 \\ \text { Files looked up, } D_{S} & 20\end{array}$

$$
\begin{aligned}
\text { Benefit } & =\left[D_{S} f+P\left[t+D_{S}+S_{P}\left(14 t+D_{s}(c+4 t)\right)\right] / 60\right] N_{r} k \\
& =[20 \times 4+1(6+20+25(84+20(27) / 60] 100 k \\
& =0.32 \text { man-year. }
\end{aligned}
$$

\section{Query Reports}

For one study, for each sample, check the parameter for a match; if found, Iist the result or status.

$$
\begin{array}{lr}
\text { Studies, } \mathrm{P} & 1 \\
\text { Number of reports, } \mathrm{N}_{\mathrm{r}} & 500 \\
\text { Files looked up } & 1 \text { (the parameter file) }
\end{array}
$$

Benefit $=\left[f+\left(P s_{P}(c+t)+D_{S} c\right) i 60\right] N_{I} k=0.04$ man-year.

\section{Form Letters}

For one study, we assume 10 values are transcribed, and the time to type a 200-word letter at 60 wpm is saved. 
Number of reports, $\mathrm{N}_{\mathrm{r}} \quad 100$

Files looked up

10 (one value for each of

10 parameter files)

Benefft $=\left[10 f+200 / 60+S_{p} D_{s} t / 60\right] N_{r} k=0.09$ man-year

Work Accountability Reports

During any one-month perfod we estimate 11 studies will have accountability data; of these, eight studies were begun during the month and three studies carry over. The status of each analysis and the dates started and completed are tallied. The title and subelement of the studfes are listed.

$\begin{array}{ll}\text { Number of reports, } \mathrm{N}_{\mathrm{r}} & 12 \\ \text { Studies, } \mathrm{P} & 11 \\ \text { Files looked up, } \mathrm{D}_{\mathrm{S}} & 20\end{array}$

$$
\begin{aligned}
\text { Benefit } & =\left[D_{s} f+P\left(2 t+3 S_{P} D_{s} c\right) / 60\right] N_{r} k \\
& =0.10 \text { man-year. }
\end{aligned}
$$

Updating Files for Status and Results

A status is kept for che study, each sample, and each parameter. We assume two updates of each during the course of a study. Six itens are transcribed for each parameter: result, unlts, operator, date done, status, and QC approval. We assume updates are done in batch fashion twice a day.

$\begin{array}{lr}\text { Studies active, } P & 4 \\ \text { Files looked up, } D_{S} & 20 \text { (parameter files) } \\ \text { Parameters in progress/day } & 2 \\ \text { Number of days/yr, } N_{r} & 250\end{array}$

$$
\begin{aligned}
\text { Benef1t } & =\left[D_{s} f+\left[\left(P+S_{p}+6 P S_{p} D_{s}\right) t / 60\right] N_{r} k / T_{p}\right. \\
& =0.32 \text { man-year. }
\end{aligned}
$$




\section{Quality Control Report and Updating Files for Quality Control}

This report is not so well defined that modeling is justifled at present. From the discussion in Sec. 5 we have estimated that 0.5 fTE would be required to achieve the desired quaity control.

The rough estimate given by AFO for time spent in performing the functions in Table 4-1 was 1.6 man-years/year. The staff at AFO has increased by two since then. If one considers that a number of the functions are neglected or done less frequently than desired because of a lack of time and personnel, it appears that the 2.3 man-years benefit estimated here is realistic and reasonable. 


\section{Appendix 5 . \\ Estimates Used in Developing Manpower Costs}

In Table 1 (Section 5 of the text) estimates are given for the cost savings expected as a result of automating the AFO laboratory. Manpower costs used to estimate these savings are based on the following assumptons and calculations.

1. Basic average salary as of Octoher 1974 is a CS-9 at $\$ 12,000-13,000$ jer year.

2. The goal for the average salary is a GS-11 at $\$ 14,000-15,000$ per year (not including allowance for inflation).

3. Assume a salary of $\$ 13,000$ per year as the average cver the first five years of the computer's life.

4. Add a payrol1 burden of $33.5 \%$ to take care of pensions, health plans, insurance, etc.

5. Add a support burden of $16.3 \%$ to take care of secretaries and adtitisistrators.

6. Add a general overhead of $66.5 \%$ to take care of building rent, custodial care, utilities, travel, etc.

$$
\$ 13,500 \times 1.335 \times 1.163 \times 1.665=\$ 34,900 \text { per man-year } .
$$

This figure checks elosely with a best guess of $\$ 35,000$ per man-year made by 0 . Villa of the AFO laboratory. An estimate of $\$ 43,000$ per man-year was given by B Fairless of the CRL Region V laboratory in Chicago. 


\title{
Appendix 6.
}

\section{New Personnel Skills and Capabilities Recommended for the Automated Laboratory}

\author{
(Prepared by Bruce P. Almich, ERC Cincinnati, 7/1/76)
}

The purpose of this appendix is to provide the management of a prospective automatable client laboratory with a concise description of the new skills and capabilities required so that planning and implementation in the areas of training, manpower allocation, and (if necessary) hiring may be carried out before the system is installed. This appendix is also designed to serve as an operational policy cornerstone for client-ERC-LLL-vendor maintenance relationships.

The new operational functions and responsibilities required in an automated laboratory are divided into two broad areas: laboratory utilization, and computer system maintenance. The two areas require different personnel skills and capabilities. Within the area of laboratory utilization two functional subdivisions exist:

1. Using the system as a means of processing aralytical samples. For example, conducting a dialogue with the computer as it executes the instrument control and data acquisition/manipulation programs.

2. Modifying programs, as required, to tailor them to the specific needs of the laboratory. Modifications by the laboratory scientist are limited to changes in the basic programs in such areas as output report format, data reduction procedures, etc.

Within the computer maintenance activity, three subdivisions exist:

1. Hardware maintenance and upgrades. This includes handling the computer vendor's service contract, as well as responsibility for maintaining the custom electronics hardware involved. These skills are detailed below.

2. Maintenance and upgrades (if any) to instrument control and applications software. This includes assistirg the laboratory scientist in modifying programs (item 2 above).

3. Maintenance and upgrades to data management software.

The first broad skills area is associated with the day-to-day use of the system by the laboratory scientist. In order to use an automated laboratory syster, the laboratory scientist must interact with the computer, by entering data and control information in response to computer queries and prompts. This 
is done at the typewriter terminal located near the instrument. The analyst must modify his previous manual analytical procedures and methods somewhat in order to accomodate this new "man-machine dialogue." He should be aware of what actions are necessary when an abnormal condition arises: for example, when he types in the wrong thing, or injects the wrong sample, or the computer detects or causes some sort of error. As his famillarity with the system increases over a period of the first two months of production operation, the laboratory scientist should become able to spot and correct human, instrument, or computer malfunctions quickly himself and to clearly present che symptoms of more involved problems to the systems maintenance person for action. These direct system utilization skills are acquired by the laboratory scientist in several ways:

- Working visits to ERC Cincinnati for tutorlal instruction before delivery of the system. This includes observation and use of a similar autowated instrument or procedure by the prospective new client, under the guidance of a scientist who is already using these skills.

- Remote access to an existing lab systern computer (via dial-up terminal) for the purpose of learning the basic language and instrument program dialogues prior to system delivery at the client's site.

- Tutarial sessions given by the automation installation team at the client's site during the system installation phase.

- Self-study of the operational documentation provided with the system for the use of each instrument and facility.

As the laboratory sclentist becomes more familiar with the use of his automated instrument, he wlll probably want to modify and extend the capabilities of the BASIC applications software as follows:

1. He may want to streamline the instrument setup and operation dialogue once he has gained famillarity with the inputs the system needs to carry out his analyses. (Example: Shorten "ENTER NURER OF SPIRED SAMPLES" to "SPIKES?")

2. He will want to convert runtime selectable options (provided with the delivered system) to program constants in order to save time, in the event that the inputs would not need to be changed during a normal run in the future. (Example: Remove variable input prompt "SPIKEs?" above, altogether, and convert if to a program constant.) 
3. He may want to change the instrument data-reduction algorithm to accommodate a special datamanalysis requirement or to implement a new analysis method.

4. He may want to change the structure, content, or appearance of an output report.

To do these things, the analyst must spend some time in learning additional details of the BASIC language interpreter and the specifics of the structure and operation of the currently implemented BASIC program for his instrument. The depth of knowledge required is, of course, dependent on the degree of program modification desired. Again, Informal course work and selfstudy are required. For the good of everyone involved, the analyst should also learn how to produce good documentation for the programming changes he makes in the delivered BASTC code. He should make every effort to keep the documentation for the automated operation of his instrument current and accurate. He assumes local software support responsibility for any programs in which he substantially modifies the disk file or the operational logic structure from those of the delivered system. Local responsibility is also assumed for local post-delivery modiftcations to the sample file control interface, to the extent that a single agancy-wide SFC may exist in the future.

The first broad skills area thus represents a reallocation of existing laboratory efforts and skills to effectively use the automated system. For each analyst, new skills are required in order to interact with the computer in performing laboratory analyses. For the elementary skills, no programming training or knowledge is required. For the optional and highly desirable purposes of modifying the delivered package of BASIC language applications software to meet unique post-delivery requirements, it is necessary to acquire programming skills in the BASIC language. This language is the simplest, most flexible general programing facility avallable and is typically taught to high school students in mathematics classes as well as being a required study area for most technical undergraduate and graduate university degree programs. Cumulative experience within EPA indicates that the operational instrument dialogues are eastly learned. In-house modification and enhancenent of the delivered BASIC programs by EPA Laboratory personnel is also being accomplished, albeit at a fairly low level at the present. Table 6-1 summarizes the above discussion, in terms of milestones and estimated resource requirements for training in the first broad skills area. 
Table 6-1. Summary of training reguired in the broad skills area of laboratory utilization. Asterlsk ( $(*)$ means optional item.

\begin{tabular}{|c|c|c|}
\hline & Milestone & Resources required \\
\hline 1 . & $\begin{array}{l}\text { Learning how to use the system } \\
\text { as delivered (tutorial course } \\
\text { given at installation time). }\end{array}$ & $\begin{array}{l}1 \text { man-wk/analyst, } \\
1 \text { man-wk/instructor. }\end{array}$ \\
\hline 2. & $\begin{array}{l}\text { Learning how to spot and correct } \\
\text { malfunctions. }\end{array}$ & First two months of use. \\
\hline 3. & $\begin{array}{l}\text { Predelivery orientation (dial-up } \\
\text { or travel to ERC Cinctnnati). }\end{array}$ & 3 man-days/analyst. \\
\hline 4. & $\begin{array}{l}\text { Introductory course/study in } \\
\text { BASIC (*). }\end{array}$ & $\begin{array}{l}1 \text { man-wk/analyst, } \\
1 \text { man-wk/instructor. }\end{array}$ \\
\hline 5. & $\begin{array}{l}\text { Advanced topics in BASIC ( } * \text { ) } \\
\text { (required for extensive program } \\
\text { modifications). }\end{array}$ & $\begin{array}{l}1 \text { man-wk/analyst, } \\
1 \text { man-wk/instruc: ur. }\end{array}$ \\
\hline 6. & $\begin{array}{l}\text { Training or self-study in pro- } \\
\text { gram structure ( } * \text { ) (making } \\
\text { full use of the system). }\end{array}$ & $\begin{array}{l}\text { Learned during first } 9 \text { months } \\
\text { of operation, by motivated } \\
\text { users. }\end{array}$ \\
\hline
\end{tabular}

The second broad skills area is associated with the maintenance of the overall laboratory automation system, as a collection of hardware and software elements, including instruments, interfaces, compute:s, and programs. For convenience, the term "inhouse maintenance person" is defined as a composite for the skills and capabilities required in this area, although these skills may be either cuncentrated in one or two people or shared among several in an actual laboratory situation. The following summary of hardware and software classes is provided for reference in the subsequent discussion:

Two types of software:

1. System: NOVA/ECLIPSE assembly language, vendor-supplied (Data General Corp.), and LLL/EPA-developed.

2. Applications: Standard high level languages. BASIC Interpreter code for instrument automation and data reduction, and sample file control (SFC) applications language (unchosen).

\section{- Three types of hardware:}

1. Computer (maintained under service contract, cost $\$ 1000 /$ mo).

2. Custom hardwrre (destgned and developed by LLL/EPA) Includes terminals, cables, connectors, instrument interfaces, computer interfaces, etc. 
3. Lab instmuments (e.g., Technicon AutoAnalyzer, Perkin-Elmer AA, etc.).

With these classes and the three functional maintenance activity subdivisions mentioned earlier in this appendix in mind, we can now define the maintenance activity,

\section{MAINTENANCE OF THE EXISTING IABORATORY AUTOMATION SYSTEMS}

The primary responstbility of the malntenance person is to keep the varj.ous hardware and software system elements in full working order by applying the techniques of preventive and remedial maintenance as well as installing hardware and software upgrades, as required. In the preventive mode, the following represents the major activity and responsibility elements:

- Monitor the computer hardware maintenance contract and see to it that the computer receives $\mathrm{l}$ is monthly preventive malntenance service from Data General, as provided in the contract. Keep Data General apprised of problem areas with the equipment.

- Periodic inspection (for example, offline testing, and observing the production operation) of the custom and lab instrument hardware to ascertain proper operation,

Periodic backups and library maintenance of all sof tware disk files. Backups should be made in triplicate on magnetic tape, with an indexing system for locating disk file images on the tape. A backup should be made of the affected progam and data flles whenever a net investment (or replacement cost) of people time in these files exceeds an average of $4 \mathrm{hr}$ of work per laboratory analyst or computer programmer.

Remedial maintenance is required when something breaks, whereas preventive maintenance is something one does to minimize the frequency, losses, and rest jration costs of unforeseen breakage. The in-house remedial naincenance skills required are those needed to successfully complete the following sequence of events whenever something breaks:

1. Identify the symptoms of the problem and find out wlich instrume:ts, users, and system operating functions are affected.

2. Isolate the problem to the subsystem level: for example, to one of the three types of hardware in the system.

3. If the problem is in a lab instrument, initiate in-house, contract, or out-of-contract extramural service repairs. (It 1s extremely important to 
have minimum administrative delays in placing service procurements with escablished, reputable service organizations.)

4. If the problem is in the custom EPA/LIL hardware, inftiate in-house repairs. Begin by swapping in working spares at the plug-in module level. (Note: the client lab should have a full complement of replaceable spare parts for all custon hardware on site; this is recommended to all clients wlo do not have ready access to a large electronics and mechanical hardware stockpile.) If difficulty is encountered in this process, assistance may be had from another client, ERC Cincinnati, or ultimately, LLL through ERC. ERC will provide a list of recommended tools and troubleshooting/repair equipuent, if requested.

5. If the problem is in the computer, two deteminations must be made next :

A. The problem must be tdentified as a hardware or software problem.

B. The problem must be identified as a "Data General" problen or a "non-Data General" problem. Lack of caution here can result In a premature commitment to expensive out-of-contract vendor service.

Generally, if the problem is in the computer hardware and is present when either Data General diagnostic or unmodified Data General system software is running (with the LLL custom hardware interface board renoved), Data General may be called in for free in-contract repairs. If the problem is in the agency-wide supported version of the operational software, a second client lab or ERC CincinnatI may be called for immediate consultation and, if necessary, assistance. In the absence of local resources, all other cases are handled on an individual basis, with the primary resolution responsibility placed on the client lab and its local resources. In-house hardware repairs and modifications should not be made on Data General hardware. Other electronic repairs snould be carrled out at the module/board replacement 1 evel. Purchase of electronic troubleshooting and replacement equipment is up to the client, but ERC Cincinnat1 will consult in the process if requested. Parts list and avallability information for custom electronic and mechanlcal hardware should be kept in good order.

The bottom line (1.e., governing principle) on maintenance policy for EPA lab antomation 1s; 
- Agency-wide support (that is, all support external to the client lab) is available for all hardware and software as delivered and made operational by the installation team, as well as for all agency-wide supported upgrades.

- Depending on the nature and extent of local post-installation modification to the delivered system and the adherence to agency-wide upgrades, post-delivery support levels from all sources external to the client laboratory will vary. Generally speaking, "If you change ic, you support it, even if the person who changes it goes away." Undocumented changes cannot be supported by anyone. The Data General service contract with GSA is a handy reference in this area.

Another aspect of the maintenance person's responsibility lies in assisting the laboratory staff in making workable changes and additions to the delivered package of applications software. At present, this is limited co the BASIC instrument programs and does not include sample file control applications activity. In an operational situation, the maintenance person has historically become closely involved with the lajoratory-scientist training milestones 1-4 (Table 6-1), as instructor and consultant.

The remaining area of responsibility for the maintenance person on the existing system is in the installation and testing of hardware and software upgrades, An upgrade occurs in one of the following circumstances:

- If the client lab determines that it has a need for additional hardware or software which is not on the "agency-wide support" list, the lab can take responsibility for designing, obtaining approval for, and implementing the new facility. This can be a very involved and complex process, especially the modifying of system software and the obtaining of headquarters approvals.

- If a proposed upgrade is determined to have rpplicability on an agency-wide basis, external support can be had for its implerentation. In these cases, a system design is performed, approvals are secured, and the implementation is accomplished with the assistance of ERC Cincinnati. This is the preferred procedure for adding a new instrument to the system. An ongoing example of this is the agency-wide maintenance of the Data General systems software subscription service, distributed by ERC Cincinnati and installed as appropriate in all laboratory automation sites.

Some of the systems level upgrades are required to be maúe on all machines in order to extend performance, fix system bugs, and assure applications software transportability. These are easily performed at the client site since the only skills required are the ability to use the Data General 
operating system command language and the text editor. More complicated upgrades in software may be handlea by directly loading a client computer with operating software via telecommunications with the ERC Cincinnati facilities.

\section{MAINTENANCE WTTH ADDITION OF A SAMPLE FILE CONTROL}

Up to this point, the skills and capabillties required for maintaining existing automated laboratory functions have been discussed. When a sample file control or laboratory data managenent function is installed, however, additional skills will be required to maintain the delivered system and install upgrades in this software area. Although this function is grouped under the computer maintenance activity area above, the exact means by which $1 t$ will be carried out are undetermined at this time. The following notes represent guidelines of current thinking as to how post-delivery support of the data management facllity should be carried out:

1. A choice between two courses of action will have to be made fairly soon. The most desirable and cost-effective route will be to develop a single, agency-wide SFC package which can be modified to suit the needs of the individual laboratory. The alternative is to develop unique systems for each laboratory or, better, each lab type, i.e., regional-production, researchproduction, instrument-automation/manual-data-entry mixes, and researchresearch.

2. With the deciston in item 1 above made, it is quite likely that a laboratory which chooses to implement an SFC capability w111 need to modify tise delivered programs for one of two reasons: (a) the delivered system did not meet the original needs due to remoteness of the implementer, etc., or (b) needs of the lab change over time and the applications programs must be modified to meet them.

3. Give 1 and 2 above, the type of support required to modify the delivered packages is not presently avallable or even potentially available to most EPA Laboratories, either in-house or on a service basis from places such as the Regional ADP office. This type of support is unique in that it represents akill reguirements from the "Business ADP" areas of computer technolugy, and thus is shaxply differentiated from the skills described above, which are - ore directly obtainable by most BPA Laboratorles. 
4. It is presently felt that some sort of SFC capability can be developed and installed for the laboratory environment (although the computer hardware performing these functions may not be best located in the laboratory itself) and used with very little post-delivery modification until the proper skills are made available to the laboratory. In most cases, it appears that the source and management of these skills should be the Regional ADP Branch, although it also appears highly desirable to have the technical person performing these activities physically located or assigned to the actual laboratory location.

With the above in mind, cne can limit further definition of the skills required to maintalr the SFC capability to the following:

- The skills required are those that would be found in the traditional $A D P$ operation, rather than in the laboratory scene. Therefore the person who performs these activities should be under the supervision of a traditional ADP manager.

- The manpower required for this support varies between zero man-years per year (e.g., existing lab system maintenance people can handle 1t) for a "no-modification" situation to a maximum of two man-years per year of fulltime effort for a "maximutn justiflable jodiffcation level" condition. Therefore, once designed and delivered, the maintenance of the SFC applications software will be a planning and resources management issue between the laboratory and the ADP fund administrators of the geographical area involved. Hence, Further manpower estimates will not be made for this function in this feasibility study.

How will the maintenance person be trained to provide the services to the laboratory in the second broad skills area just discussed? The following are notes on this training requirement, gained from agency-wide experience to date:

1. With the purchase of a Data General computer system, the customer is entitled to a limited number of free training credits (2 man-weeks) at one of two Data General training centers in the U.S. It is essential that 2 to 4 паn-weeks of training be gained by preferably two laboratory people before the system is delivered. Each person should obtain one week of training in Data General operating system concepts and facllities and one week in either assembly programming, FORTRAN programming, or hardware maintenance overview. It is desirable for two people to pursue this study for each laboratory in 
order for the laboratory to realize service continuity in the case of absenteeism or a job change by the trained in-heuse maintenance person.

2. Each maintenance person should spend a minimum of one week of predelivery orfentation training at a working laboratory facility elsewhere in the agency. Five to eight working days at ERC Cincinnati would be optimum.

3. Eaci maintenance person should participate actively in the installation and delivery testing phase after receiving 1 and 2 above and obtain an additional week of training from the installation team members at delivery time,

4. Approximately six months of post-delivery operation time will be required for the malntenance person to get up to full speed in his duties.

In conclusion, we have provided the prospective client laboratory with the above description of new personnel skilis required for the full and appropriate utilization of a laboratory automation system, by describing functions and responsibilities in two broad areas. The first area represents a reallocation of existing personnel within the laboratory. The second area can be staffed in one of the following ways:

1. One or two existing laboratory people can be trained and reassigned to perform the functions, as dId Region $V$, with no additional personnel required. This would be espectally appropriate in a small-to-medium-sized laboratory with modest post-delivery modification wishes and external SFC support. The people could be selected from those shemists with some computer background, or from existing in-house persons with electronics and some highlevel language programming background.

2. A new chemist or electronics techniclan with some previous computer background could be hired. Background in electronic equipment service and repair and BASIC/FORTRAN programing is extremely valuable. This is the most appropriate course of action for the large production laboratories with sincere Interest in proper system utilization and upgrades.

3. Items 1 and 2 above can be combined to form a working tean of "principal automation chemist" and system malntenance person, which seems like a very desirable concept for a lab engaged in large sample volume production and significant enhancenents.

4. Item 1 above can be combined with hiring a computer person whose primary emphasis would be software maintenance and enhancement. Hardware maintenance could be performed with additional extramural assistance. The 
software person would Inherit the SFC specification and maintenance function and could carry out elementary add-ons himself.

With any of the above alternatives, it is estimated that the first broad skills area should require no new hiring. The minimum requirement for the second skills area is no new hiring, in a lab environment of well-motivated in-house chemists with previous computer backgrounds, little wishes for enhancements, and external SFC support. The most probable situation would be hiring one new chemist or engineer/technician for the minimum support level by the maintenance person of 0.5 man-year/year. The maximum new personnel requirement would be 2.0 man-years/year, which would provide full in-house hardware and instrument/SFC software support, maintenance, and upgrades. In this cost/benefit analysis 1.0 man-year has been allocated to the system function for the recommended system.

ERC Cinclnnati is available to consult on these matters. 